\title{
Captures, Commerce, and Corruption
}

In October 1615 the Generalitat of Catalonia sent a protest to the Council of War. Prince Emmanuel Filibert of Savoy, recently appointed captain general of the sea and charged with revitalizing the Mediterranean galley squadrons, had required it to pay one-tenth the value of all prizes seized by the Galleys of Catalonia as required by the ancient rights of the admiralty, which his office had inherited. ${ }^{1}$ The dispute, which had arisen a year earlier, awakened a longstanding fear of the Catalan deputies: that the ample jurisdiction granted to the prince could interfere with their control of the galleys they armed and the profits they earned from them.

The Galleys of Catalonia, like all the Catholic king's other squadrons, enjoyed enormous privileges. By an agreement made in 1599, the Generalitat had to impose a series of fiscal charges to cover, first, the 80,000 libras assessed for arming the four galleys, and later the squadron's annual operating costs. To do so, it pledged to commit the bolla (a kind of customs duty) of the city of Barcelona and to levy tariffs on the sale of playing cards, the export of fruits and vegetables, grain, wine, oil, fish, and certain textiles, and the import of silk from Valencia, wool from Castile, and leather. ${ }^{2}$ In exchange, the king granted the Catalans the right to export, free of any type of tax, 500 salmas (a measure of tonnage) of Sicilian wheat a year and up to 48,00 o Castilian ducats annually. They were also allowed to purchase all those "munitions, provisions, and other things necessary for those galleys, free of all tariffs, paying the fair price for them," and were exempt from any other duty, including the one owed to the admiralty, on the profits they earned from seizing ships. ${ }^{3}$

Clearly these privileges, common to the jurisdiction of all galley squadrons, granted Generalitat deputies exceptionally favorable access to every market under the Hispanic Monarchy. Their intent was to ensure the survival of the expensive squadron, but of course they also offered many chances for its managers to enrich themselves. In fact the Marquis of Almazán, viceroy of Catalonia during the dispute with the Prince of Savoy, had complained repeatedly about the situation. Though the squadron had been sailing for only a few years, the deputies showed scant interest in keeping it operational; they armed only

\footnotetext{
1 AGS, GyM, Consulta del Consejo de Guerra, Burgos, 9 October 1615.

2 Gilabert Tomàs, "Defensa."

3 AGs, Estado: Consulta del Consejo de Estado, 23 January 1615.
} 
two galleys a year and devoted them to prize-seeking, so as to profit from their built-in commercial advantage. ${ }^{4}$ Under the circumstances, it was natural for the Prince of Savoy to seek some of those gains, and for the Generalitat to feel that its share of the profits from the galleys was under threat.

This problem was well known and affected galleys beyond Catalonia. The Hispanic Monarchy routinely exempted owners of corsair ships from paying taxes on the prizes they seized. ${ }^{5}$ The measure, designed to encourage defense of the coasts, also brought continual conflicts because many persons motivated only by "greed for prizes" committed excesses. ${ }^{6}$ This problem could never be resolved, but it has served, first, to define the relations between the monarchy and the merchants who conducted its maritime trade, ${ }^{7}$ and second, to explain one of the squadrons' commonest responses to the high death rate among rowers and the need to preserve themselves at all costs. Just as in privately armed ships, Philip Williams explains how the nature of each squadron was based on the logic of prize-seeking, on the success or failure of a type of warfare in which one either attacked or was pursued. If a galley were to maintain itself, its resources — above all, slaves— had to come from seizing enemy ships. ${ }^{8}$

By analyzing this theory we can explore the second jurisdictional dimension that captains general of the galleys inherited from the old admiralties: their power over trade, maritime trade in this case. We can then assess the effect of ship captures on the finances of the galleys, specifically those of the Galleys of Spain. More broadly, we shall consider the role of capture in Mediterranean commerce and whether its judicial practice affected conflict resolution in cases of prize-seeking, smuggling, and embargoes.

\subsection{Ship Capture and Its Benefits to Crews}

Each galley squadron had a different profile, and all varied in the specific economic gains they made from corsair activity. Letters to court by officers of the Galleys of Spain speak of their chronic need for rowers and their occasional

4 AGS, GyM, 796: Marquis of Almazán to Philip III, 6 December 1614.

5 AGs, Estado, 1945: Consulta del Consejo de Estado, 23 October 1615.

6 AGs, GyM, 8oo: Consulta del Consejo de Estado, 26 March 1615.

7 Ruiz Ibáñez, "Juegos de azar"; Ruiz Ibáñez and Montojo Montojo, Entre el lucro y la defensa.

8 Williams, Empire and Holy War, 51, 114. 
captures of large numbers of new slaves at sea. These facts suggest that the squadron depended heavily on prize-seeking to maintain itself, especially since its leaders were always lamenting their lack of financing. The royal galleys had to protect the Peninsula's long Mediterranean coast, the supply routes for North African outposts, trade across the Strait of Gibraltar, and the galleons that sailed to and from the Indies; on every watch, they came into contact with all sorts of ships, making it easy to seize precious resources, especially human ones. Luckily, their account books reveal this economic activity in fairly complete form for several years in the early seventeenth century, allowing us to gauge the impact of corsair activity, an important aspect of their commercial privileges, on their finances and manpower. This time spans a period of lowlevel warfare ${ }^{9}$ that also saw the definitive stabilization of the office of auditor in 1605 .

Some scholars have remarked on the Hispanic Monarchy's difficulties in defending certain strategic routes. Beatriz Alonso, for instance, noted the problem in the Oran-Cartagena passage, which became a veritable hunting-ground for North African galliots during the crucial summer months. ${ }^{10}$ Less has been written about the Spanish advantage on very short routes, like that between Tétouan and Algiers, where North African merchants sailed in the same season. In June 1616, Gabriel de Chaves, captain of a galley that seized many prizes during those years, captured a 200-ton ship on that route manned by about a hundred Turks and Moriscos.. ${ }^{11}$ Three years later, the Galleys of Denia, a satellite of the Spanish squadron, heard that the Algiers flagship, loaded with merchandise, had sailed alone out of Tétouan. They decided at once to give chase, spurred by the rumor that it carried goods "of great value" - between gold, silver, jewels, pearls, purple dye, and many Jewish, Turkish, and North African captives who might be ransomed, the first estimate hinted at a fabulous fortune of several hundred thousand ducats. ${ }^{12}$

These examples, and others we could cite, suggest that the Galleys of Spain could have realized enormous gains from their corsair activity. One hundred captured slaves could have solved the shortage of rowers at a stroke, and the treasure from the flagship, distributed to the crews, might have solved the economic problems of all their soldiers and sailors. But in the event, 70 of the 110 people seized in 1616 were Moriscos who were set free, while the galley's cargo was swindled away in the twinkling of an eye (a lawsuit was brought for fraud),

9 Jamieson, Lords of the Sea, 78-79. See Williams, "Strategy."

10 Alonso Acero, Orán-Mazalquivir, 46o-66.

11 AGS, Estado, 813: Consulta del Consejo de Guerra, 8 June 1616.

12 AGs, GyM, 846: Consulta del Consejo de Guerra, 2o December 1619. 
so that we do not know its actual value or whether the crew gained anything from the prize. ${ }^{13}$

Despite some grandiloquent pronouncements, the usual fortunes of the Galleys of Spain in the early seventeenth century were much more modest, as their account books reveal. Although not every ledger registers sales of prizes or the resulting income, we do find traces in the accounting from 1605 to 1611 and 1614 to 1619 . For the first period, we see a ship sold in 1605 for a little over 1,150 ducats, paid at public auction by a town councillor of El Puerto de Santa María. Curiously, there was no further sale before December $16 \circ 8 .{ }^{14}$ We do know that another prize from the period, a ship that Pedro de Toledo captured in 1607, was auctioned for 97 ducats but sold only in 1610; therefore, it appears on the books for the period 16o9-11, during which time no other such sale is recorded. The accounts are somewhat out of phase with the sales of captured ships, which tended to accumulate-in 1614-16 there is record of a few small payments for two Turkish ships seized in Málaga, probably sold between 1612 and June 1614 , a period for which we have no data. ${ }^{15}$

Two ships were sold in the second half of 1614 , a small one taken at Gibraltar in June and auctioned for $15^{2}$ ducats, and a Moorish settee captured by Captain Chaves in July along the Barcelona coast and knocked down for 187 ducats. In 1615 , total income was similar but came chiefly from other settees that Chaves had seized the year before. In January, Jacome Rebella of Barcelona, a merchant captain, bought a Turkish settee captured the previous December for 120 ducats, while Francisco de Acosta of the same city acquired a Turkish ship —one of the ones seized in 1614-for 1,386 ducats. At an unknown date Domenico Barrile, a resident of Cartagena, became the owner of an Algerian ship called Nuestra Señora del Rosario and all its cargo for 4,279 ducats, and we find the sale of the Tétouan galliot that Chaves took in 1616 for 250 ducats. ${ }^{16}$

Finally, among sales of prizes for the period 1617-19, a Turkish caravel taken at Tétouan in February 1617 was sold to a resident of El Puerto de Santa María for 145 ducats. In this case, the cargo too is recorded - the more than 400 arrobas of oil it carried brought 600 ducats, 100 jars of olives brought 40 ducats, and 34 quintales of figs brought 50 ducats. We also know that Chaves, while conveying the Duke of Feria to Italy, captured two settees, one in Peñíscola and one in Oropesa, and sold them immediately at auction, with all their rigging,

\footnotetext{
13 AGs, GyM, 858: Melchor de Borja to the Marquis of Santa Cruz, 28 August 1620.

14 AGS, CMC, 3 ápoca, 1436.

15 AGs, GyM, 795: Accountant Miguel de Luyando to the king, El Puerto de Santa María, 6 April 1614.

AGS, CMC, 3 a Época, 2940-41.
} 
sails, and artillery, to Gabriel Sanza of Peñíscola for 410 ducats. ${ }^{17}$ In all, in the fourteen years of campaigning that include $1605^{-11}$ and 1614-19, the books of the royal accounting office (Contaduría Mayor de Cuentas) list sales of prizes to a value of about 8,717 ducats, to which we should add two more sales from 1611 that are not described in full detail and not included in the total.

Of course these accounts may contain errors. A letter of June 1618 relates that a galley en route to Seville seized a brigantine with twenty-three North Africans and two Christians aboard, but there is no record of its sale, probably because it was not bought until $1620 .{ }^{18}$ We know that in May 1616 another North African ship, pursued by the Marquis of Santa Cruz off Fuengirola, went to the bottom, so of course it was never sold. Other ships may have sunk as well, but there are no great discrepancies when we compare records of sales with the squadron's correspondence. It is curious that auctions of ships' cargoes are mentioned only twice, but perhaps most ships simply contained little of value - many of the captured vessels were small, and almost half of them brought less than 200 ducats at auction, while two others brought less than 300 ducats.

In light of all this, it seems that for the Galleys of Spain no great gains derived from corsair activity along the coasts, since captured prizes were relatively few; instead, there were occasional windfalls that had little effect on the squadron's total income. Certain monies did accrue to officers, however, if they were able to collect them. The accounts record that Captain Gabriel de Chaves received a stipend of 100 ducats for his active role in prize-taking, though as often happened, that amount was paid out only in small occasional sums. The ledger for ${ }^{1602-3}$ mentions that a commission had been charged with appealing to court for payments owed to galley captains and their sailors for prizes taken in 1591-92. ${ }^{19}$ In November 1616, the paymaster Fernández de Villegas, returning to his post after an absence, found that only 260 ducats from sales of prizes had been recorded. ${ }^{20}$ Captains general sometimes made improper use of those funds. In 1599, the Marquis of Santa Cruz spent some on new dresses for his sister Doña María, just named lady-in-waiting to the queen. ${ }^{21}$ Many stipends from the monarchy to crew members had to come from sales of prizes, and it was essential that payment be made regularly; it was problematic, therefore, if that failed to be done. ${ }^{22}$

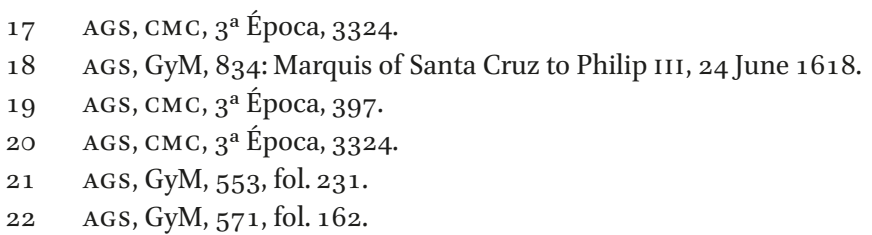


Even captains general had trouble collecting their share of prizes. Emmanuel Filibert of Savoy did not collect what was owed him as captain general of the sea $(3,200$ ducats for the period 1612-16) until 1618. The Marquis of Villafranca, who had ceased to be captain general of the squadron years before, was still drawing small sums in 1618 on the value of the prize taken in $1611 .{ }^{23}$ Unsurprisingly, both men demanded their back pay in a bitter lawsuit that lasted for years. ${ }^{24}$ The profits from sales of prizes were so small and so late that in most cases the galleys' paymaster would satisfy those delayed debts with amounts that the Genoese Vincenzo Squarciafico, based at court, drew on his agents in Seville. ${ }^{25}$

\subsection{Acquisition of Slaves}

One might object here that our analysis ignores the immediate benefit gained from seizing ships (a larger number of rowers) and the income derived from the sale of human beings, which was a factor in other Mediterranean squadrons. ${ }^{26}$ But even here the account books tell another story, though the data they offer are few. During our fourteen-year period there is only one brief reference to a deposit from a collective sale of slaves captured by the Galleys of Spain. On May 30, 1617, a bill of 4,90o ducats was presented in Seville for an "order of payment to the Commissioner General [of the Crusade] for 158 slaves and three Moorish ship captains whom the Galleys of Spain took in prizes captured between the year 1610 and February $1617 .^{27}$

The amount is correct. By the 1607 ordinances, slaves captured by the squadron could be sold only to the king, at the price of 30 ducats a head and 100 ducats for North African captains, giving us a total close to that of the bill. ${ }^{28}$ But we must ask if this was really a sale of surplus "stock" to the king. It might represent instead an accumulated payment for all the slaves taken during those seven years and now serving in the galleys, to be distributed among the crews, after discounting the jewels (the captain general's portion, usually the best valued slave), according to each man's allotted share of prize money. Unfortunately, because the books are in disorder and the paymaster's distribution policy is unclear, we cannot tell if the sum was actually shared out. We must look elsewhere to learn whether a seizure of large numbers of slaves by the squadron could lead to this type of sale en masse.

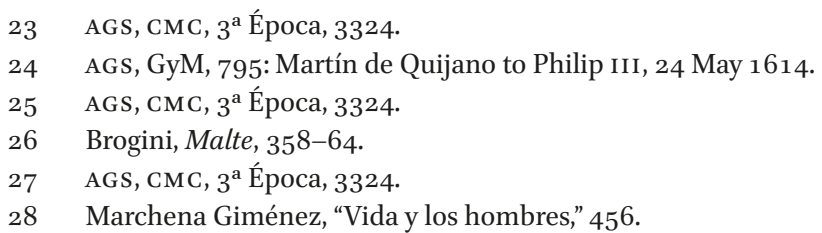


We first find that the Galleys of Spain made a purchase from the Galleys of Catalonia in February 1615. For the sum of 2,700 ducats, they bought 87 slaves captured by the Catalan squadron, again at the official price of 30 ducats per head, seeming to confirm the shortage of slaves just at the time mentioned in the letter of May $1617 .{ }^{29}$ We can relate this purchase to the normal practice in those years, by which the Council of War gave the squadron large occasional sums for buying slaves; that also suggests that the squadron was usually a buyer, not a seller. During our period, there is a single reference to a deposit for that purpose, of 14,000 ducats in 1608, but accounts from 1608 and 1609 register no large purchase of slaves. Therefore it appears that, except for certain special opportunities like the one in 1615 (there was another in 1610 that we will discuss below), those monies were spent in other way. ${ }^{30}$ Perhaps, instead, individual slaves were bought at intervals over time, so that although there was a large budget for slaves, the need for them was not really so pressing.

There are a few entries for slaves bought from private owners. Between 1605 and 1608 only two sales were recorded, three slaves in 1607 and two in 1608 , from residents of El Puerto de Santa María, Cartagena, and Cádiz, for a total of 361 ducats. ${ }^{31}$ Larger purchases were made during the next three years. In 16o9, in seven transactions, twenty slaves changed hands at a cost of 1,945 ducats. The next year only two were bought, though for a high price of 309 ducats, and none was bought in $1611 .^{32}$ We can conclude that around the time of the large bank deposit of 1608 , only twenty-seven slaves bought from private owners entered the galleys, for a total price of 2,615 ducats (i.e., about 96 ducats per head).

This limited number of sales acquires meaning if we compare it with the sales of "useless" slaves in the period 1605-8. Throughout 1605 , the galleys sold eight slaves who could no longer row, one in January, one in February, two in August, and four in December. Curiously, they were bought by members of the squadron itself. The wife of the purser Juan Alfonso de Molina bought one; another purser, Durango, bought two; the secretary Bartolomé Rincón, one; Bartolomé de Alzate, probably related to a third purser, Carlos de Alzate, also bought one; and the Count of Niebla, former captain general of the squadron, two. Their total cost was 290 ducats, and if we add another 80 ducats from a ransom, the average price of an individual was 53 ducats (i.e., almost double the rate the king paid, even though these slaves were "useless").

\footnotetext{
29 AGS, CMC, 3 ápoca, 2940-41.

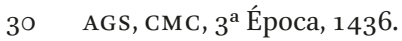

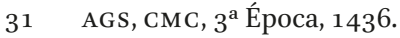

32 AGs, CMC, 3 Época, 1570.
} 
The year 1606 saw similar stories. That year, four slaves were sold - to the captain of a galley, the purser Molina's wife again, Dr. Jerónimo de los Cobos (the galleys' physician), and the private citizen Juan Ocampo-for an average of 42 ducats. In 1607, only one slave was sold, for 30 ducats, to a resident of El Puerto de Santa María, though we could add two female slaves confiscated from an indebted supplier, at 148 ducats for both, and a ransomed man for 60 ducats. No sale took place in $16 \circ 8 .{ }^{33}$ During the next three years, 1609 saw the sale of Hamete from Tétouan for 20 ducats, Alí from Larache (who had lost a leg to a cannonball) for 54 ducats, and another ransomed man for 72 ducats. No transactions occurred in 1610, and in 1611 the only one involved a ransom. Those four sales came to 206 ducats, so over the three years the total number of individuals bought or ransomed was nineteen, for almost 1,00o ducats in all. ${ }^{34}$

Therefore at this period the sum spent on buying slaves was more than double that earned from selling them, based on twenty-seven bought and nineteen sold. It is reasonable to suppose that, as the ordinances allowed, the income from sales was reinvested in new purchases as opportunities arose, and that the uneven market prices (since a useless slave cost less than a healthy one) were compensated for by the Council of War's special fund. It seems clear that galley officers were particular beneficiaries of the few slaves sold by the squadron. Because of high prices, they would prefer not to fill their benches with rowers from public slave markets except on rare occasions.

Another source of purchases came not from individual sales but from the captain general's privilege of buying shipwrecked men, inherited from earlier times of the admiralties. It was rare to obtain slaves in this way, and there is no case in the account books before 16og. The first one registered involved a single North African from a Moorish brigantine that ran aground at Cádiz; he was bought for 9o ducats. ${ }^{35}$ The detail is significant because, in 16oo, the Count of Santa Gadea had bought five slaves shipwrecked off Tarifa for more than the official rate set by the king for galley prizes, opening a debate about whether their price should be fixed at 30 ducats; apparently, that had not occurred. ${ }^{36}$ In December 16og there was a larger shipwreck in Ayamonte involving thirty-four men. After some talk of taking them to Portugal, ${ }^{37}$ in the end thirty of them ended in the galleys according to the accounts from 1610. In 1611, another eighteen slaves were taken from a shipwreck in Cabo de Gata, but there is no record

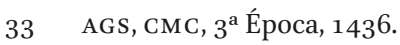

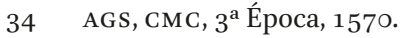

35 AGS, CMC, $3{ }^{\text {a Época, } 1570 .}$

36 AGs, GyM, 566, fol. 173 .

37 AGs, GyM, 727: Duke of Medina Sidonia to Philip III, Sanlúcar, 30 December 1609. 
of their sale prices, only of the cost of transporting them. ${ }^{38}$ In all, shipwrecks provided forty-nine slaves in only those three years, bought with the special fund set up in 1608. Rights to shipwrecked men were obviously a significant element to be added to those captured through fighting on the high seas.

We cannot understand the makeup of the galleys' slave population in these years without considering the largest and most significant source of slaves in the first two decades of the seventeenth century-the Morisco rebellion that broke out in the kingdom of Valencia in October 1609, which proved of enormous benefit to the Galleys of Spain. Letters written at the end of that year show that the Marquis of Villafranca had managed to channel into the squadron a good portion of the Moriscos who had been enslaved after their defeat. The approximate number was two hundred men, ${ }^{39}$ and an account-book entry for 1610 confirms that the total might even have been slightly larger. On April 30, 1610, the Galleys' paymaster noted an outlay of 2,274 ducats for 224 Morisco slaves from Valencia, an average price of 10 ducats per person. ${ }^{40}$ This was the lowest amount paid for any purchase in the years under study, and shows how the galleys probably benefited from the saturated slave market in Valencia after the uprising. At the same time, it explains why there were so few purchases of new slaves in the years following.

It is much harder to calculate the number of new Moriscos who joined the galleys through captures of North African ships in the following years, because those who could prove their noninvolvement in corsair activity could be deported again. For example Andrés Hernández, a Morisco from Baeza and a slave on the galley San Martín, had been taken aboard her with four other slaves in August 1613. The squadron had paid a private citizen 20 ducats for him, but less than a year later he could show documentary proof that after being sent to North Africa, he had decided to turn Christian; he had sailed for France with a skipper, who cheated him and cast him ashore at Marbella, where he had been caught and sold into slavery. On reviewing his case the Count of Salazar, the commissioner of the expulsion, ordered him freed and he was sent back to North Africa in April 1616.41

Even while Moriscos were increasing the ranks of slaves, the dearth of captures soon returned the squadron to its usual state of scarcity. Doubtless one reason was not its lack of skill but competition with the Armada of the Ocean Sea, which was sailing in the same waters at the time. ${ }^{42}$ Just as in June 1615 ,

38 AGs, CMC, 3 ápoca, 157 o.

39 Lomas Cortés, Puerto de Dénia, 219.

40 AGS, CMC, 3 ápoca, 1570.

41 AGS, CMC, 3 ápoca, 2940-41.

42 AGs, GyM, 813: Consulta del Consejo de Guerra, 8 June 1616. 
when rowers had had to be bought from the Galleys of Catalonia (their surplus had perhaps inspired the Prince of Savoy's demand for part of their profits in that year), in June 1618 a similar deal was made - the purchase of thirty slaves from the galleons of the armada which, since just the beginning of that season, had already seized four ships. ${ }^{43}$

In short, not only did the Galleys of Spain find it difficult to fill their rowers' benches with their own captures; neither could they buy many slaves from civilians on shore nor make up their numbers with shipwrecked men, although the latter formed an important component. Clearly, the chief source of slaves for the galleys was other royal squadrons, from which men could be bought at a fixed, lower-than-market rate that depended on current supply and demand. Our data suggest that the payment order for the 158 slaves captured from 1610 to 1617 referred not to the sale of surplus men (the Galleys of Spain had no surplus in those years) but rather to the exact number of slaves seized from captured ships who ended up on the rowers' benches. On the theory that a squadron's operations and prestige were measured by its success in prize-taking, it seems that the Hispanic Monarchy's oldest and best-known squadron had a series of bad years where slave capture was concerned. It remains an open question whether, as a result, the number of rowers fell to a dangerously low limit.

We have no account of deceased slaves for the full period, and lists of rowers must be treated with caution because (possible cases of fraud aside) they rarely offer a periodic, total count of the squadron's men. But one useful document is a report prepared by the Dorias in 1638 that calculates the cost of maintaining four galleys for the kingdom of Sardinia, which reveals that under normal conditions the average death rate was eight slaves per galley per year. ${ }^{44}$ If we accept this figure, assume that the Galleys of Spain had the same number of slave rowers as contracted galleys, and recall that this squadron consisted of nine vessels in those years, we can conclude that it needed about seventy-two new slaves per year. In the decade $1609-18$, for which records are fairly complete, 573 slaves came aboard (though the number would be slightly higher if it included purchases from private citizens between 1612 and 1618 ). Therefore, throughout the decade, the squadron seems to have been able to replace, in one way or another, about fifty-seven of the seventy-two new men required each year. These incomplete data suggest that the squadron was more or less able to maintain its crews, though the general tendency was negative, a fact

43 AGs, GyM, 834: Emmanuel Filibert of Savoy to Martín de Aróztegui, Madrid, 19June 1618.

44 ADP, scaffale 70, busta 24: "Calcolo della spesa necessaria per mantenimento d'una galera ordinaria della squadra del signor principe Doria." 
explained in part by its falling back on reinforced galleys. ${ }^{45}$ The main problem was the small number of captures, though we must note that slaves formed only a small part of the rowers in this squadron-most of the men were convicts. ${ }^{46}$ To fill out the picture of the income produced by the galleys' actions at sea, we must consider not only the struggle against the Turks but also commercial warfare with Christian enemies of the monarchy.

\subsection{The Audiencia de las Galeras and Embargoes}

In December 1598, the recently crowned Philip III proved his intent to continue the war in Flanders by decreeing the seizure of every Dutch ship then trading along his coasts or able to be captured at sea. ${ }^{47}$ Only a few days later, the king announced the first results: six vessels taken in Guipúzcoa, two in Galicia, twenty-four between Oporto and Lisbon, nine in the Algarve, five in Ayamonte, fifty-seven between Sanlúcar, El Puerto de Santa María, and Cádiz, three in Seville, six in Cartagena, and two in Alicante. Other important jurisdictions such as Málaga had not yet reported their numbers. ${ }^{48}$ Though there is no record of the Galleys of Spain having made any specific capture, their officers played an important role. Half of all the seizures passed through the hands of Alonso de Velasco, the squadron's inspector general, who had been charged with applying the edict on the coast between Sanlúcar and Cádiz; he was helped by its auditor, who inventoried the ships and their cargoes and arrested their crews. ${ }^{49}$

The galleys benefited from these embargoes just as they did from capturesby appropriating the rowers and selling the ships. We do not know the end result, but early in the process, by December 16 , the galleys had gained seven maestres (merchant captains), six contramaestres (boatswains), and seventythree seamen..$^{50}$ These numbers must have increased as captured men arrived from faraway ports, though we know that many remained in prison and never boarded a ship. Our information about ship auctions is also incomplete, but in March 1599 the six vessels seized in Cartagena were still waiting to be sold for the squadron's benefit (and the captured sailors were still awaiting the arrival of the galleys where they would serve). According to the purveyor Miguel de Oviedo, their assessed value was 9,200 ducats, a significant sum. In just a few

\footnotetext{
$45 \quad$ Williams, "Past and Present."

46 Heras Santos, Justicia penal, 312.

47 Gelabert González, "Entre 'embargo general'."

48 AGs, GyM, 561, 26-3o.

49 AGs, GyM, 561, 76.

50 AGs, GyM, 539, 187.
} 
months from 1598 to 1599 , and in just one port, the squadron had apparently earned from these seizures more income than from the sale of prizes taken in all of 1605-11 and 1614-19, though we must treat this information with caution. Miguel de Oviedo also reported that the ships had been knocked down for less than their asking price when no buyers appeared, and in the end some of them even had to be sold on credit. ${ }^{51}$

It is easy to see how this situation arose. The auction price of ships might have fallen because such a large number had been embargoed. But above all, once the embargoes had been decreed, many merchant captains appealed the auditor's decisions, making him justify whether "it is a legitimate prize or not, and where they come from" before an auction could be held. Because the process was not always simple or conclusive, purchases must have become even more uncertain - and this was not the only problem caused by the edict. ${ }^{52}$

The auditor Mosquera de Figueroa wrote that cases involving galleys should be brief and efficient, avoiding "the scrupulous rigor of ordinary judges," because the forms, rituals, and "substantial ... superstitions of common law" created delay and "loss of time" that worked against the needs of an army on campaign. Therefore when a auditor prepared his cases, he should not give "occasion for seeking out lawyers"; he should avoid at all times "the loud chattering of prosecutors, the damaging ruminations and irrelevancies that some lawyers, with a narrow reading of the law, use to persuade and, if they can, to change the judge's mind." Nor was he obliged to "listen to litigants when they wished to speak to him privately; [they should speak] publicly in his court, so that cases can be better understood and decided swiftly." The auditor was not bound by "the practice of civil, canonical, or municipal law, which are characterized by the written exposition of the case, a response by the opposing side, assignment of times and deadlines, the appearance of witnesses, and documents, without which ordinary justice is nothing." 53

\footnotetext{
51 AGS, GyM, 541, 163.

$5^{2}$ AGs, GyM, $548,88$.

53 " $[\mathrm{L}]$ a vocinglera parlería de los procuradores, las dañosas cavilaciones y impertinencias con que pretenden persuadir algunos abogados, con un cierto rigor de derecho, para derribar si pueden la voluntad del juez ... [sin obligación de] oir a los litigantes en particular cuando le quieren hablar en secreto, sino públicamente en su tribunal, para entenderse mejor las causas y acertar en ellas brevemente ... [No está ligado a] la práctica del derecho civil, canónico y municipal, que consiste y se diferencia por la presentación del escrito, contestación del pleito, asignación de términos y plazos, producción de testigos y escritos sin los cuales el juicio ordinario no es ninguno." Mosquera de Figueroa, Comentario, fols. $112 \mathrm{~V}-114 \mathrm{~V}$.
} 
The elements needed for sound and swift military justice were not limited to the squadrons, but followed the type of summary judgment outlined in the judicial system of Castile, as María Paz Alonso Romero explained years ago. ${ }^{54}$ That system allowed for a prompt decision on the fate of a corsair ship and was occasionally applied to merchant ships and other types of Mediterranean commerce. On the nearby coasts of Muslim lands, a "plain and sincere" eyewitness statement could carry more weight than a written document when two parties sought a quick resolution and preferred not to go to court. ${ }^{55}$ On the other hand, when auditores used the same procedure, they could become persons "of absolute power and a strong hand," 56 making their decisions a threat not only to crews and ordinary magistrates but also to skippers and armers of ships.

In September 160o, a group of galleys brought the auditor Juan Ossorio to Huelva. On disembarking, he ordered an armed troop of soldiers to enter the town and arrest two residents, Diego Juan and David Barbero, and a French merchant, "Pablo Guillermo," on charges of avoiding the embargo by trading for the Flemings with their own ships, thus eluding seizure. Ossorio then confiscated their merchandise, valued at more than 5,00o ducats, together with an unknown sum of money, "causing a great uproar." The local magistrate soon objected that those acts impinged on his jurisdiction, that the three wellknown residents had been unjustly charged, and that the auditor had exceeded his authority in applying the embargo to men who were good subjects and faithful Catholics. Besides, since the galleys' people were not involved in the case, he demanded a full report and the immediate return of all seized persons, vessels, cargoes, money, and legal briefs. The magistrate wrote to the Council of War, which replied that it first needed to study the case, requiring copies of all briefs and their assessment by an expert. ${ }^{57}$ With any decision thus delayed, there would be no immediate auction of the ships, but nor would either side in the case receive prompt satisfaction.

This type of conflict with the regular justice system, which arose from jurisdiction over offenses against the laws of maritime commerce, was as common as those involving crimes that seamen committed on land. It almost always followed the same pattern: a auditor ordered an embargo and passed sentence within a few days; a local official, usually a corregidor, objected and appealed

\footnotetext{
54 Alonso Romero, Proceso penal, $287 \mathrm{ff}$.

55 Greif, "Contract Enforcement."

$5^{6}$ AGs, GyM, 846: Consejo de Guerra, 1619.

57 AGs, GyM, 572, 361 .
} 
the case; and everything was delayed while the Council of War weighed in on the jurisdictional dispute. Occasionally, however, the roles were reversed.

In January 1605, several merchants of Cádiz brought suit against Adam Veart before the corregidor of El Puerto de Santa María. That skipper, a native of Havre-de-Grâce, had anchored in Cádiz for a few days while he bought salt to take to the fishing grounds off Newfoundland, but the men of Cádiz insisted that he was really a pirate. Three years before, while they were trading in North Africa under license, Veart had boarded their ship and stolen their cargo, and they now demanded his arrest and the seizure of his vessel. The corregidor confiscated his sails and weaponry to keep him from resisting or escaping while the charge was investigated. But as soon as the inspector of the galleys learned of the situation, he embargoed the ship, arrested its crew, inventoried its cargo, and forwarded the case to the auditor, who called on the corregidor to relinquish it. The judge advocate insisted that since it involved a crime of piracy at sea, it fell under the jurisdiction of the captain general.

The case seemed complicated at first. Because Veart had changed ships and crews since the incident of three years before, he claimed that the present embargo and arrest were illegal. He was only a quarter-owner of the company, so the auditor was trampling on the rights of the other owners. But these arguments proved useless. No one expected a quick decision, because of the jurisdictional dispute involved, and the Council of War had not yet been consulted on whether the auditor could take the case away from the corregidor of El Puerto and whether an embargo could be declared at all. But in short order the arrested seamen were already rowing in the galleys and the Duke of Medina Sidonia had requisitioned the vessel for guard duty in the Strait of Gibraltar. ${ }^{58}$

Sometimes jurisdictional disputes arose even between different military units, inevitably with the ships' armers on the losing side. In December 1604, a merchant vessel from Emden, a German port near the border with Holland, loaded with wood from Galicia to transport to Seville, was seized off Lisbon by a ship from Dunkirk bearing letters of marque from Archduke Albert of Austria and his archduchess, Philip II's daughter. The corsairs had boarded her believing that she belonged to an enemy ("from a bad country"), but after identifying the cargo and its origin, they realized their mistake. Reluctant to lose any possible profit, however, they towed her to a bay near Cascaes and demanded 500 escudos in exchange for her captain's release. But the governor of 
the local castle, informed of their presence, alerted the ships of the Armada of the Ocean Sea, just then anchored in Belem. While the corsairs and their prize were soon in the hands of the squadron, the captain of the German ship was still very far from seeing justice done.

On the one hand, the armada's auditor claimed the case because his ships had captured the corsairs. On the other, the auditor general of the kingdom of Portugal asserted his own right to it, because soldiers from regiments under his jurisdiction had served on the armada, boarded the corsair and its prize, and arrested the crew. As an additional complication, the auditor of the Galleys of Portugal also claimed a role - the armada's people, unable to tow the two ships themselves, had asked his galleys for help in bringing them into port, and therefore his own squadron had taken part in the capture and he, too, had a right to hear the case.

Each side began to prepare its briefs while calling on the other to withdraw. The first to leave the field was the auditor general of Portugal, but his colleagues continued the fight to defend their own interests. The galleys wished to declare the Dunkirk ship a legitimate prize and auction it off, but the armada sought to seize it by embargo for its own squadron; it would receive no economic benefit, "because His Majesty does not consider as prizes ships that are embargoed for his service and manned by people from his armadas." In March 1605 the Council of War called on both auditores to show proper deference to each other. But what interests us most is that after four months of litigation both ships were still stranded in port- the auditor of the galleys was still not entirely convinced that the German vessel was not an enemy one - at great financial cost to their armers and crews. ${ }^{59}$

Faced with all the usual delays that resulted from appeals against the auditores' decisions, some chose simply to accept their jurisdiction. In June 16o1 some of the armada's ships, together with the Galleys of Spain, captured five Flemish vessels as they tried to cross the Strait. Because the Count of Santa Gadea commanded both squadrons at the time, he put the auditor of the Galleys in charge of the case. Each ship was to be charged separately, and statements would be taken from officers and crewmen, through several interpreters, over a period of days.

All the testimony pointed in the same direction. Four of the vessels were Dutch, though armed by different people, and had been returning to Amsterdam after trading in several Italian ports; near Málaga, they had decided to form a convoy to defend their cargoes against the dangers of the Strait. The 
fifth ship was not Dutch but had taken the precaution of joining the others, and so had been caught along with the rest. With this information in hand, the auditor arranged several "plenary trials," a type characteristic of Castilian summary justice. In each trial the crews' statements were verified and each captain was asked "if he wished to defend himself in the case and claim his right to justice, for which he would be assigned a lawyer, a representative, and a stipend." But all the skippers declared that they had no defense to present, that their shipmates' statements were true, and that they would accept their sentence. All they asked in return was freedom to go home with their men. As a result, after a two-weeks trial on 14 July, the auditor confiscated the four Dutch ships and their cargoes "as a legitimate prize" and ordered the crews set free. He decreed that the fifth ship could continue its voyage, and offered its captain safe-conduct in exchange for a fine of 200 maravedis for having traveled in such bad company. ${ }^{60}$

Mosquera de Figueroa explained that although auditores were exempt from all the ceremonies of common law, they should conform to those of natural law and the law of nations. In doing so, they had to respect the three principles that effected, informed, and decided any trial and without which their jurisdiction could not operate nor their "court" be legitimate: confessions, necessary proofs, and legitimate defense. ${ }^{61}$ It appears that the trials of the Dutch ships involved the practical application of Mosquera's legal doctrine, since it was based on witness statements and respected the skippers' right to a legitimate defense. It is not so clear that other proofs were considered, but in this case the captains agreed to the process, and the auditor may have found the offense to be flagrant.

The captains did have the right to an attorney and a representative, but demanding them carried its own risks. The month of July 1601 happened to be an intensely busy one for the auditor of the galleys. Aside from the case of the Dutch ships, he faced the complaints of a group of Irish merchants and merchant captains whose vessels and cargoes had already spent some time embargoed in Cádiz and El Puerto de Santa María. In that case the crew, having spent two weeks on the rowing benches while the auditor considered their crimes, had claimed their rights and sent a delegation to the court in Valladolid asking for help. While awaiting a reply, they had spent all their money on food. When their case was finally heard and they were set free, they found their ships too damaged to put to sea, and for both repairs and sustenance they would need

6o AGs, GyM, $582,81$.
61 Mosquera de Figueroa, Comentario, fol. $114 \mathrm{r}$. 
the funds that they were now, unsuccessfully, demanding from the Galleys of Spain. ${ }^{62}$

There were times when a ship's crew and its cargo suffered different fates. On September 7, 1598, a few weeks before the general embargo was declared, a Dutch vessel was seized because it came from rebel territory. In this case, its captain and the French merchant who had chartered it demanded their rights, so the galleys' appeals court (the Audiencia de las Galeras, as the scribe Leonardo Garguillo called it) heard the case. It was an example of the second sort of procedure that could take place before that body. A lawyer and interpreters were sought, and the licenciate Pedro de Armenta was named as defender and representative of the ship's absent armers, its captain Juan Garbaransen, and the French merchant Rocher Bolin. It was decided that for the opposing side a supervisor of the galleys, Juan López, would represent the royal property of the Catholic king. After five weeks of arguments the auditor found against the ship's captain and its armers, declaring it forfeit along with its artillery, powder, weapons, rigging, sails, and supplies. But while sentencing the captain and crew to row in chains, he freed Rocher Bolin, together with all the cloth and other merchandise in the hold, based on clauses in the recent Peace of Vervins. ${ }^{63}$

There is no mention in this trial of intervention by the French ambassador to help free Bolin and his cargo, but diplomatic pressure was often exerted in such cases. The usual complaint was that captains general of Spanish squadrons were not only pursuing Muslim ships but also seeking prizes from other nations, in an attempt to "take [from them] for supplying their galleys." This was the charge leveled against the Spanish ambassador in London, Pedro de Zúñiga, in 1607, after the Galleys of Portugal were said to have "seized large sums of money from different English [ships] for payment" of the squadron. Its captains general, the Count of Elda, had to prepare a report containing statements by several Englishmen that denied such seizures and showed, with an example from 1605, that he was obeying the terms of the Treaty of London. In September of that year, his galleys had captured an English ship loaded with cod that was sailing off Cape St. Vincent "without a passport and without the permits required by the treaties and capitualtions." The auditor had initially held that the seizure was legitimate, but a royal order had forced him to reverse himself, even though the ship and its cargo had been "properly condemned." ${ }^{4}$

\footnotetext{
62 AGs, GyM, 581, 76.

63 AGs, GyM, 561, 218.

64 AGs, GyM, 684, 116, and 120.
} 
Such gestures were not unusual. In August 1618 John Digby, England's envoy extraordinary to the court of Philip III, requested that twelve Englishmen condemned to row in the Galleys of Portugal be freed. The Council of War reviewed their case and, though some of them had been sentenced for piracy, decided to release them; it recalled that James I of England had freed about one hundred "priests and laymen who were condemned, some to life in prison, for their Catholic religion" as a favor to the Spanish ambassador in London, the Count of Gondomar. ${ }^{65}$ We observe here how galley squadrons could serve not only as instruments of warfare but also as tokens of peace and amity between princes; treaties usually included clauses that guaranteed freedom of trade between their respective countries and the mutual freeing of men sentenced to serve in their ships.

For example in February and March 1599, in accordance with the twentieth provision of the Peace of Vervins, ${ }^{66}$ all French prisoners were removed from the squadrons - though men of that nation soon returned to them, as we see in a document from 1613. In May of that year the French consul in El Puerto de Santa María called on the Prince of Savoy to respect a decree by Philip III freeing all French prisoners, in particular those who were in the galleys awaiting the outcome of their trials. The captain general of the sea replied, however, that the only Frenchmen serving in the squadrons had been definitively condemned. He attached a list of their names, crimes, and sentences, giving us an insight into the severity of sentencing by the Audiencia de las Galeras in those years, at least as it pertained to the French.

In 1613 the ten Galleys of Spain held fifty-two Frenchmen among them. Only four of those had been sentenced for crimes related to piracy, and only two had been tried before a auditor. The rest had arrived from up to fifteen tribunals from all over Castile. The majority came from Madrid, Granada, and Valencia, and their commonest crime was robbery. Aside from thieves, there were rapists, murderers, adulterers, impersonators of soldiers, profaners, and blasphemers, though only two were serving life sentences. Sixteen were sentenced to six years, fifteen to four years, and eleven to ten years; therefore very few had served since the beginning of the century. The longest-serving prisoner in the squadron, Ramon Butar of Toulouse, had been rowing since the Audiencia of Valencia had imposed his life sentence in 1602. Most of the men (forty-two) had arrived in the galleys between 1609 and 1612 . We can conclude that during

65 AGs, Estado, 2515: Consulta del Consejo de Estado, 18 August 1618.

66 Haan, "Dernière paix." 
this period an average of ten Frenchmen a year were sentenced to the galleys, only two of them for crimes of piracy, in 1611.67

There are several ways to interpret the absence of seamen from the 1613 lists. Some sentences condemned the ship and its cargo but freed the crew, especially if the men acknowledged their responsibility, as the four Dutch crews did in July 1601. There was also the effect of diplomatic pressure. In 1607 the French ambassador intervened with the Council of War to free three corsairs from Havre-de-Grâce from the galleys: Jean de Lone, Dionis de Nigule, and Thomas Venart, the last of whom could be the Adam Veart accused of having robbed merchants from Cádiz off North Africa in 1605, or perhaps his brother. It seems they had served a year and a half of their ten-year sentences, and although their crimes were serious, the council judged that by showing them mercy "on other occasions the same thing [may] be done in France for subjects of Your Majesty."68 It is unsurprising, then, that when two ships (from Holland and Danzig) were intercepted near Algiers in July 1609 without "the right dispatches" (making them susceptible to capture), it was decided to grant them "liberty without taking anything from them, so as not to create lawsuits over issues of interest, and to remove opportunities for ambassadors to present complaints, even if they are unjustified." 69

It is hard to determine how far these practices extended. As with all aspects of the administration of justice in the galleys, the summary and expeditious nature of the auditores' decisions defies systematic analysis. Few of their trial records have survived, because only a few of those cases appealed to the Council of War are known. We can only guess at many others, since embargoes did not count as prizes and therefore appear only rarely in the account books. In only two ledgers have we found a specific section on embargoes, for the periods 1614-16 and 1617-19. From them, we learn that on August 17, 1616, the galleys embargoed a French ship in Cartagena, though they received no immediate benefit pending appeal of the case to the Council of War. Up to that point, the seizure had produced only expenses (for bringing Fray Juan Bressae to the port in December to hear the prisoners' confessions, for guarding the vessel, and for preparing reports of the case to send to the council). The accounts also reveal that in November 1617 the council finished reviewing another appealed embargo, of a ship taken in Barcelona from Domingo Felipe, who was already serving

67 AGs, Estado, 2643: Consulta del Consejo de Estado, 14 May 1613.

68 AGs, GyM, 669, 337.

69 "[L]ivertad sin thomales ninguna cossa, por no llevar pleitos en materias de intereses, y quitar las ocasiones que desto toman los embajadores para formar quexas, aunque no sean justificadas." AGs, GyM, 726: Luis Fajardo to Philip III, 1 August 16og. 
a ten-year sentence as a rower. In that case, the squadron was able to auction off the ship for almost 4,20o ducats. At about the same time, another embargoed ship was awaiting the result of its case in Seville. The ship embargoed in Cartagena in 1616 finally saw its cargo sold (the exact date is unknown), bringing a little more than 6o ducats from the auction of 26 quintales of wheat. ${ }^{70}$

Though there is little information about income, we can also consider spending. Between 1614 and 1616 the squadron paid somewhat more than 3,0oo ducats for prizes and another 1,400 ducats for embargoed ships. ${ }^{71}$ With the exception of special decrees like Philip III's in 1598, respect for treaties, diplomatic negotiations, and lengthy appeals to the Council of War largely limited any economic benefit to the galleys from the application of laws of commerce; at least for 1614-16, those embargoes brought in less money than prizes did, although corruption could also have played a part.

Throughout these years, there was constant criticism of the auditores, especially for abuses they committed. In November 1598, for instance, the auditor of the Galleys of Spain was sued for threatening men with the rowers' benches if they disagreed with his imposition of the general embargo. ${ }^{72}$ In fact, the Council of War set up a committee to investigate his actions during the process, and although proof of his offense was hard to establish, both he and his scribe were arrested and accused of appropriating part of the profits from the embargoes. ${ }^{73}$ The network of depositaries and guarantors was so extensive that it is difficult to follow the trail of the stolen funds, which eventually emerged only in small quantities. ${ }^{74}$

During these months, a lawyer from El Puerto de Santa María perpetrated another fraud, helped by his former title as auditor of an infantry regiment. Passing himself off in Lisbon as the auditor for the Galleys of Spain, he unlawfully seized several German vessels and condemned them for almost 2,ooo ducats. His deceit discovered when the seizure was appealed to the Council of War, he was imprisoned on a bond of 10,000 ducats, the estimated value of everything he had stolen. ${ }^{75}$

In 1607 the squadron's auditor - the real one this time-was again denounced for fraudulent dealings with the embargoes. It seems that in 1602 he had impounded a ship from Calais for smuggling and exacted a fine of 8,ooo

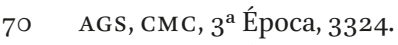

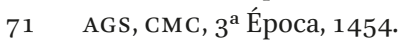

72 AGs, GyM, 561, 63 .

73 AGs, GyM, 564, 254.

74 AGs, GyM, 565, 278.

75 AGs, GyM, 677, 787 . 
ducats, but soon afterward the viceroy of Portugal accused him of exceeding his authority and taking on several cases relating to the embargo against the Dutch that rightly belonged to the auditor general of the kingdom. Investigation revealed that he had defrauded the royal treasury of more than 20,000 ducats. ${ }^{76}$ Clearly, the embargo business could prove very lucrative not only for the squadron but also for its auditores, though official accounts may not reveal the fact (among other reasons, because they too were fraudulent). It is clear from all this that as squadrons and their tribunals achieved permanent consolidation, they conditioned and changed maritime trade in the zones that fell under their influence.

In a recent work on corsair warfare and the right to prize-taking, Rita Loredana Foti explains how different monarchies, in trying to dominate the seas, constructed a legal doctrine in which the principles of the law of war (ius belli) were combined with other motives arising from commercial law (ius mercatorium) — such as the need to safeguard Christian interests at sea—and the law of prizes (ius predae; the latter fell under the jurisdiction of the old admiralties which, since the thirteenth century, had regulated captures at sea and the legal cases resulting from them). ${ }^{77}$ This doctrine, by employing the discourse of the crusade, justified the corsair aspect of the war against Islam ${ }^{78}$ but was also applied to commercial competition with Christian enemies. We recall that Hugo Grotius published his Mare liberum in 1609 in response to new pressure by the Hispanic Monarchy against Dutch maritime trade. ${ }^{79}$ It is reasonable to consider whether Grotius's work arose from such circumstances (the consolidation of squadrons and of their jurisdiction over trade through auditores' courts, which were acquiring their definitive outlines in those years). Further, we can multiply the actions of the Galleys of Spain by those of ten or twelve other active squadrons. An undoubted result was a more efficient form of naval warfare, together with speedy resolution of lawsuits related to smuggling. All this could produce, or encourage, new reflections on the limits to control of the seas and to freedom of navigation. We must also ask whether captains general of the squadrons were conscious of these doctrines when they challenged a Christian merchant ship or attacked a Muslim vessel (whether legal discourse made them implacable defenders of the crusade or if, on the contrary, space still remained for contact and collaboration). We must determine to what degree

76 AGs, GyM, 677, 787 .

77 Foti, Giudici e corsari, 17-44.

78 Fontenay, "Place de la course."

79 García Arias, "Estudio preliminar." 
squadrons like the Galleys of Spain, in their incessant search for resources, could benefit from their proximity to North Africa, beyond the sale of prizes and the contraband activities that they, too, in theory, ought to pursue.

\section{Cross-Cultural Trade and Control of Smuggling}

In early July 1618 three galleons from the Armada of the Ocean Sea spotted a flotilla of eight vessels that were flying no flag. King Philip III had ordered the armada, together with the Galleys of Spain, to block the Strait of Gibraltar against a Dutch fleet; therefore the Spaniards, unable to determine the ships' origin, sent a caravel to approach them peacefully and ask who they were. The strangers made no answer "any more than as if they were mute," but scarcely had the caravel drawn away than they "raised a red banner of war with the arms of Venice and ... without saying more ... fired all their artillery." 80 The episode helps to explain how the initiation of combat could be justified and when a seizure was considered legitimate. According to the auditor Mosquera de Figueroa, before any fighting began there should be an attempt at peace to avoid "the spilling of blood." That should be accomplished through ambassadors bearing an offer of peaceful relations, similar to the behavior of a squadron when it solicited entry into a port-in a show of good will, it would accept a visit by local authorities. In encounters at sea the squadrons should play that role, demanding acknowledgment of the Catholic king's precedence. They then had the right to board the opposing ship and, if warranted, to seize it and arrest its crew.

An attack on the sacrosanct person of the ambassador-which the Venetian ships had been careful to avoid in 1618 - was a justification for capture; as Mosquera explained, that had happened on Terceira Island when the Marquis of Santa Cruz's emissaries had been fired upon, giving them ample motive to launch the invasion. ${ }^{81}$ While many documents reveal such captures, others describe encounters between squadrons and suspected corsair ships in which the latter allowed the galleys to approach, board, and conduct an inspection, after which they were free to sail on. Only if they resisted by fleeing or firing on the galleys could they be pursued, boarded violently, and captured. Whenever the galleys were the stronger force, it was prudent to cooperate with them, especially in the face of a possible embargo. That was why the captains of the four

8o ASv, Segretaria di Stato, Spagna, 6oE, fols. 218-2o.

81 Mosquera de Figueroa, Comentario, fols. $34 \mathrm{r}-35^{\mathrm{r}}$. 
Dutch vessels brought before the auditor in July 1601 had pleaded to be freed on the grounds that none of them had resisted boarding. ${ }^{82}$ Dutch and German ships in July 1609 had escaped punishment by "entering the armada asking for Simón Dançer"; that is, they approached voluntarily as a sign of peace. Reports on that particular incident help us to analyze how well captains general understood the legal doctrine that protected their actions in war, and through them we can also study the collaboration that lay behind those conflicts.

\subsection{Between Religious War and Collaboration: the Action of Tunis, 1609}

Many actions involving galleys, even if taken against the infidel, had a purpose beyond the predatory; sometimes, they reflected concrete political aims of the monarchy. One example was the expedition in July 1609 that destroyed twenty-one ships belonging to the English corsair Howards ("Uguarts" in Spanish documents) and to Kara Uthman Dey ("Cara Çumanday") in the Bay of Tunis. According to the official report, the profit derived from the attack was only 50 reales, because the occasion "was about service to Your Majesty, and the one thing [sacking the ships] could not be achieved without impeding the other." 83 In fact in 1601 Gian Andrea Doria, writing to the viceroy of Sicily, had expressed concern that some at court believed "that prize-taking is prejudicial to the galleys" and wanted the activity forbidden; though the prohibition never happened, there was clearly a debate about its possible benefits. ${ }^{84}$ The most interesting aspect of the Action of 1609, however, was that, after the attack, the Spanish fleet was kept in the bay for three days by bad weather, requiring some minimal communication with the Muslim authorities-especially after the Dey had sent a letter demanding an explanation for the aggression. Luis Fajardo's reply, and the final response he received, have survived among the reports on the Action that were sent to the Council of War, and they clarify why Fajardo admiral of the Armada of the Ocean Sea argued that the law was on his side and the Dey denounced the injustice he had suffered.

By the account of the fleet's admiral, the attack had been organized "to punish the pirates who in this Mediterranean sea, against the laws of Our Lord God, of justice, and of nature, are robbing ... and worrying ... and disturbing the Christian republics and destroying their subjects' trade." As Francisco de Vitoria explained, the only just cause for war was a grave offense that threatened the survival of the republic. ${ }^{85}$ The same principle had obtained in Alphonse X's

82 AGS, GyM, 582, 81 .

83 AGs, GyM, 726: letter by Luis Fajardo, 4 August 1609 .

84 ADP, scaffale 85, busta 22: Gian Andrea Doria to the Duke of Maqueda, 2 November 1601.

85 Peñera, "Estudio introductorio," 127-33. 
Partidas - that the only reasonable motive for war was protection of subjects and their property and revenge for an enemy attack; ${ }^{86}$ jurists of the Hispanic Monarchy naturally invoked this legal principle to justify the role of the galleys. The Catalan Cortes, in creating the Galleys of Catalonia in 1599, had argued that Turks, Moors, and other enemies - all corsairs and pirates-were interfering with trade through their attacks and robberies, enslaving Christians and separating them from the Catholic faith, and forcing subjects of the monarchy to spend great sums on ransoming them, funds that the infidels later used to increase their fleets and redouble their attacks. ${ }^{87}$ This disturbance of the peace, damage to the patrimony and honor of the Catholic king's subjects, and looming danger to the republic had given Fajardo the right to set those ships afire, especially because "as has been seen after that recent action ... they have not sought advantage from anyone"; that is, the action was not intended for economic gain. It was therefore an act not of piracy but of legitimate defense, backed by justice and God's natural law. As Vitoria had explained (following Thomas Aquinas), in such cases a defensive war could not be won without an offensive one, which could be waged legitimately as one of the eternal laws, norms, and rules that governed the actions of men. ${ }^{88}$

Fajardo's invocation of the divinity also carried a strong charge, since from the Christian standpoint the fact that the authors of the offense were enemies of the Catholic faith reinforced the legality of the response. The Alfonsine code had already noted that since Antiquity there had been three reasons for waging war, one being "for the People to increase their Faith and to destroy those who may wish to confound it." In the sixteenth century this principle established the legal discourse of opposition to the Ottoman Empire and North African Islam. Gregorio López de Tovar, in his edition of the Partidas published in 1576, devoted a long gloss to this point, full of references to earlier authorities. ${ }^{89}$

Another notable argument in Fajardo's missive was that the Spanish were responding not only to the damage to Christian republics but also to the fact that the enemy "is robbing even its own peoples, something that cannot be allowed even among barbarians." A continual point of debate among Spanish jurists and intellectuals in the sixteenth century was the idea of barbarism and the extent to which the Hispanic Monarchy could conquer and educate idolaters and bring them to the faith. Ginés de Sepúlveda and Bartolomé de Las

86 López de Tovar, Siete Partidas, 551-52.

87 AGs, Estado, 459: Consulta del Consejo de Estado, 23 January 1616.

88 Peñera, "Estudio introductorio," 105.

89 López de Tovar, Siete Partidas, 552-61. 
Casas had sparred over the issue in the congregation of Valladolid in $1550 .{ }^{90}$ Domingo de Soto, though generally sympathetic to Las Casas's position, argued in his own treatise on justice and law that one could take up arms against a tyrannical government and even overthrow it when it persecuted the Christian religion or its faithful. ${ }^{91}$ The presence of Christian captives in Muslim lands and Christian rowers enslaved in Muslim galliots legitimized the capture of ships that represented unjust Muslim rule on the seas-and, in this case, the burning of vessels that had been armed and equipped to oppress Christians.

Fajardo's reasoning went even further: "It is a wonder that the lord kings of Tunis, having such ancient obligations to the Crown of Spain and knowing its great power in the past to conquer this kingdom and many others, should wish to give occasion [for war] by protecting these robbers, a damned and excommunicated people." The comment was meant to evoke the vassalage that Charles $\mathrm{v}$ had imposed on Tunis's rulers, making the attack a just punishment for rebellious subjects; Fajardo urged them "to seek a remedy by clear signs ... and with it preserve the good concord and recognition that prevailed in the past." This affirmation of the power of the monarchy and its right even to seize the enemy's land recalls Diego de Covarrubias's words in book 6 of his Regulae Peccatum (1571): that it was not merely licit but obligatory for Christians to fight against infidels, since they held and usurped lands that had once belonged to Rome and the Christians. ${ }^{92}$ This reasoning justified the Catholic monarchs' attempts to expel Muslims from North Africa and Turkey and provided legal backing not only for assaults and occupations of those Muslim lands but also, by extension, for the attempt to banish them entirely from the Roman mare nostrum. As Miguel Ángel Bunes has noted, one of the basic defenses of the monarchy's expansion into North Africa was the notion of reviving the classical world, ${ }^{93}$ and Fajardo seems to have known that very well.

The admiral's final argument was that the Dey of Tunis had sheltered the English pirates. This was not a religious issue like the others but a breaking "of peace treaties between Christian princes and republics"94 such as sometimes interfered with embargoes, as we saw above. The treaty signed by England and Spain in 1604 established free trade between the two powers, ${ }^{95}$ so the English corsairs in the Bay of Tunis were violating it by preparing to attack Spanish

\footnotetext{
90 Soto, Controversias.

91 Soto, Controverias, libro v, cuestión III, 153.

92 Covarrubias y Leiva, Regulae, Lib. vi Part 9 \& 10, 157-207.

93 Bunes Ibarra, "Marco."

94 AGs, GyM, 726: Luis Fajardo to the Dey of Tunis, 1 August 1609.

95 Abreu Bertonado, Colección, 243-94.
} 
merchant ships, and their guilt extended to the Tunisians. But "Cara Çumanday" was not of the same mind. He replied that he did not understand the double standard and was not breaking the laws of justice and nature "by having ships that course on the sea or maintaining a free port or admitting ships of another nation," because "Christians do the same in Florence and Malta and other places in Christendom, where they arm themselves ... for these actions, from which our nation could be harmed." He was unaware of any violation except that committed by France, which, after signing a treaty of friendship with the Grand Turk, was allowing its corsairs to continue seizing and selling North African merchant ships. And he mocked the Spaniards' supposed power, recalling that "the Great Lord took and gained it from the Moorish and Christian viceroys who held it, ... and we, under his protection and shelter, do not fear the power of all the kings in the world."96

In spite of those words a cordial, though tense, atmosphere prevailed. The Dey allowed the Spaniards to land and supply themselves with water and firewood, and he offered no hindrance to their fleet until it sailed away a few days later. ${ }^{97}$ This sympathetic and collaborative attitude on both sides, once the trauma of the attack in the bay was over, is an interesting one. Luis Fajardo listed readily and fluently the chief principles employed in traditional Spanish law to justify war in general and war on Muslims in particular. Admirals and captains general of squadrons must have been aware, perhaps with the help of their auditores, of the legal framework that protected their jurisdiction at sea and along the North African coast—not only in the more complex decision of whether an embargo against a Christian owner was valid, but also when they seized, or in this case burned, a Muslim vessel. Significantly, the person Fajardo needed to convince of the legality of his action was the Tunisian ruler himself, and the latter, while answering him with equally reasonable positions, still supplied the galleys with their basic needs without hostility or a desire for revenge. Their dialogue may have been amicable because the ransom of seven Turks was also at stake (the fleet obtained almost 800 ducats for them). ${ }^{98} \mathrm{But}$ that exchange was made in a generous spirit, without seeking the royal license that squadrons required for rescuing captives (though it might have been a form of alafia), ${ }^{99}$ suggesting that the situation was far from being a clash of civilizations.

96 AGs, GyM, 726: "Cara Çumanday" to Luis Fajardo.

97 AGs, GyM, 726: Diego Vivero to Philip III, 5 August 16 og.

98 Ags, GyM, 726: Diego Vivero to Philip III, 5 August 16og.

99 Andújar, "Rescates," 154. 
Eloy Martín Corrales has observed that the prolonged corsair conflict between Christians and Muslims in the Mediterranean has kept us from seeing clearly the continuous commercial traffic between North Africa and the Hispanic Monarchy. He insists that exchanges never ceased, whether in the form of ransoms, special concessions linked to support for one side or another in Muslim civil wars (Fajardo's letter mentioned one such case of open protection and collaboration), or imports of North African wheat, on which many Spanish cities depended during times of scarcity. ${ }^{100}$ Miguel Ángel de Bunes has stressed the importance of the fortified Spanish enclaves on the North African coast, which served as conduits for exporting goods to the Iberian Peninsula. He also mentions the role of Spanish spies in that traffic, and the still little-studied illegal trade conducted by cities and certain families. (The Medina Sidonias, closely involved in Mediterranean defense, also benefited from commercial transactions that in no way resembled a religious war between irreconcilable parties. $)^{101}$ We wonder to what extent the galleys, too, while still acting as the spearpoint against the infidel, might have entered into that porous reality, which included war and misunderstanding, benefiting from the privileges of their jurisdiction and their access to the coast of Africa to make contacts that could help to maintain their crews. We will begin with the question of ransoms.

\subsection{Profiles of a Cross-Cultural Trade: Ransoms}

It is not easy to assess and quantify the ransoming of galley slaves, though according to surviving account books the commonest practice was for rowers to ransom themselves. Azambalí, a Turk, paid goo reales for his own ransom in December 1605. Amar from Tunis, a galley slave on a flagship, gained his freedom for 660 reales in June 1608 by proving that he was too old and infirm to row. ${ }^{102}$ A year later, Solimán from Bône bought his freedom for 800 reales; he was still in good health but "had turned Christian" and adopted the name Cristóbal Sánchez. In 1610, two rowers named Alí, respectively from Alcázar and Tétouan, paid their own ransoms of 870 reales: "The Marquis [of San Germán], being then in the fort of Larache, ordered them freed because he had sent them to King Muley Xeque [Mulay al-Shaykh]" to demand the official surrender of the fortress. Though still able-bodied, they obviously earned their release through this service to the monarchy as envoys and interpreters between the Spaniards and the Moroccan ruler.Juan de Alcoholado, a slave whom Doña

\footnotetext{
100 Martín Corrales, "De cómo el comercio."

101 Bunes Ibarra, "Relaciones."

102 AGS, CMC, 3 a Época, 1436.
} 
Catalina de Armijo had rented to the galleys, bought his freedom for 650 reales, that being the price at which the lady had assessed him. ${ }^{103}$

In December 1615 Juan Fornal, who rowed in a vice-flagship and was probably a Morisco from Murcia, paid 25 o reales to be released. ${ }^{104}$ We have already mentioned the case of Andrés Hernández, a Morisco from Baeza, who in April 1616 was freed after a legal suit in which the galleys were compensated for his original price, 1,10o reales. Juan Fox, a "Christian slave," had not entered the squadron of Spain after the Moriscos' expulsion, like so many others, but had served in it for more than thirty years; Emmanuel Filibert of Savoy ordered him freed because he was sixty years old, blind, and one-armed, but Juan still had to pay back his assessed price of 250 reales. ${ }^{105}$

The ledgers show, then, a total of nine self-ransomed slaves in nine years at a gain to the squadron of 500 ducats. For North African and Turkish slaves, the main motive seems to have been a combination of old age and infirmity; for some Moriscos, it was doubt about their true religious affiliation when they began to be captured at sea after their expulsion from Castile and Aragon. ${ }^{106}$ Aside from these general conditions, permission to ransom oneself was granted only in special situations, possibly through the favorable disposition of ships' officers and a good service record on board. The two rower "ambassadors" from the Marquis of San Germán seem to fit this model, as does Solimán of Bône alias Cristóbal Sánchez.

The case of Solimán/Cristóbal is suggestive. He had been allowed to buy his freedom on the basis of his conversion, hinting that that was a viable option, though Giovanna Fiume has shown that baptism did not require an owner to free a slave. ${ }^{107}$ Cecilia Tarruel has clarified that conversion might mask a wish to improve one's living conditions, hopelessness about the prospect of release, or the pressure of one's environment, and that after a slave converted, the decision to free him or her still rested with the owners. ${ }^{108}$

We find a similar case in the galleys. In April 1620, the Council of War studied a petition hand-delivered by the Marquis of Santa Cruz's secretary. The squadron's captain general requested the release of Mostafá, a Moor who had turned Christian and taken the name Juan de Ribera. The marquis had elevated him from his rowing bench to the post of body servant, and he believed that

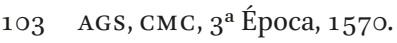

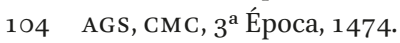

105 AGS, CMC, 3 a Época, 2940-41.

106 Benítez Sánchez-Blanco, Tríptico, 261-72.

107 Fiume, Schiavitù, 18-19.

108 Tarruell, "Circulations," 210-20.
} 
the slave had cured him of an illness. He proposed assigning another slave to row in Mostafá's place, and the council approved the request. ${ }^{109}$ The incident shows that a combination of the aristocrat's efforts, the waters of baptism, and the slave's good service record had combined to set him free.

In rare cases a galley slave might be manumitted through his owner's last will and testament; that occurred more often with domestic slaves whose owners, in the face of death, wished to clear their consciences. ${ }^{110}$ Vincenzo Centurione, who for several years contracted out two galleys for the Spanish squadron, arranged for his slaves to be freed after his decease. He made special mention of Miguel Gonzales, a rower in the San Juan who claimed to be an Old Christian unjustly treated because his mother had been a mulatto slave.111

As a rule, no one could be freed from the Galleys of Spain without paying a ransom or, as in Mostafá's case, earning the gratitude of one's captain general. Occasionally, someone tried. In May 1598 Isuf, a poor slave who had been rowing for thirty years, petitioned Prince Doria for his freedom in exchange for remaining in the prince's service for as long as his master wished. ${ }^{112}$ But almost all slaves needed a considerable sum of money to ransom themselves, and we wonder how so many could have saved enough to buy their liberty.

It is possible that the money did not really belong to the slaves and the account books conceal ransoms paid by middlemen, a common occurrence on land. ${ }^{113}$ For instance, in 1596 a slave named Barca offered Prince Doria 250 escudos for his freedom; he did not actually have that sum, but a Genoese merchant could pay a portion on behalf of his family, and a "fellow-countryman" freed in Messina could put up the rest. ${ }^{114}$ But that did not seem to be the normal case for the Galleys of Spain. The amounts paid were usually much smaller than true captives' ransoms, which ran to several hundred ducados. Nor is it likely that exchanges of captives were involved, since those circumstances were normally noted in the accounts. In September 1615, for example, when Ramadán from Algiers was freed from the vice-flagship, it was recorded that a woman from Barcelona had petitioned the king to exchange him for her husband, a captive in Tunis, for a payment of 1,200 reales. ${ }^{115}$ It is plausible, therefore, that

\footnotetext{
109 AGs, GyM, 858: Consulta del Consejo de Guerra, 27 April 1620.

110 Andújar Castillo, "Sobre las condiciones."

111 AGs, GyM, 846: Petition by Miguel Gonzales, 1619.

112 AGs, Galeras, 5, fol. 3 o.

113 Vincent, "Procédures."

114 AGs, Galeras, 4, fol. 11.

115 Ags, CMC, 3 a Época, 1454.
} 
the nine slaves mentioned above really did ransom themselves with their own money, and different types of accounts reinforce this impression.

In 1607 the squadron's paymaster entered a deposit by the captain of the galley San Francisco of 800 reales found among the belongings of a deceased slave. ${ }^{116}$ In 1611, 654 reales appeared among the goods of Azán from Valivadra, a slave in the flagship, who had been killed by a convict rower. ${ }^{117}$ When Yzá from Algiers, a slave in the royal galley, died in 1613 , an auction of his possessions brought in 348 reales. ${ }^{118}$ All three men had enough to ransom themselves if the Prince of Savoy allowed it, and point us toward some references in the ordinances of 1607. That document specified that slaves could improve their situation within a galley by assuming certain posts reserved for them, such as espalder (chief oarsman), mozo de popa or mozo de cámara (ship's boy), or mozo de alguacil (sergeant-at-arms' boy). ${ }^{119}$ They were also allowed to set up "taverns" on board and earn what must have been considerable sums, because officers were expressly forbidden from usurping them. Those small businesses were clearly meant to benefit the poorest among the crew through the sale of wine and other supplies, but they were also controversial, in that they raised suspicions that some men were selling the goods, bought on consignment from the squadron, illegally on the side. ${ }^{120}$

The ledgers tell us little about the slaves' economic activities, since financial officers did not usually deal with them, but there are scattered references to crewmens' decisions to exchange some of their food rations for cash. In July 1603 the squadron's paymaster shared out 52 reales among five rowers who preferred to take their entire wine ration for the month of May in coin. The men were one salaried rower, two Christian corulleros, and two Muslim first-oarsmen, Amuza from Larache and Hamete from Tétouan. ${ }^{121}$ Similarly, in March 1605 a Moorish slave called "Botija" accepted 95 reales in lieu of all his rations. ${ }^{122}$ Although these are our only examples, we wonder how many slaves - who might decline to drink wine on religious grounds, for instancecould sell their rations to the onboard taverners without involving a financial officer, thus acquiring some income for improving their living conditions or

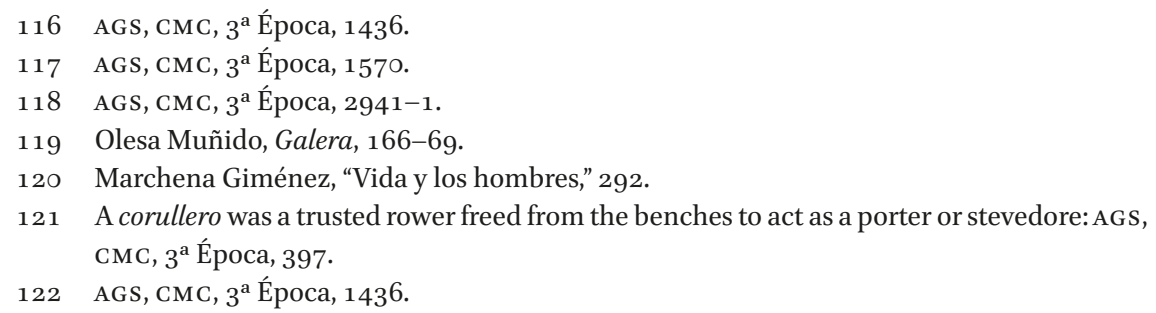


saving for a future ransom. Based on the amount shared among the five rowers, we can estimate that slaves who held special jobs had a wine ration worth about 1 ducat a month, helping to explain the accumulations of cash sometimes found among the belongings of deceased slaves.

Another chapter of the 1607 ordinances sought to regulate the vice of gambling among the rowers. Many of them bet the winter clothing that they were issued every year (two shirts, two jackets, and sometimes shoes and caps), ${ }^{123}$ and it seems that the best players were sometimes taken from one galley to another. ${ }^{124}$ We do not know just how much money card-playing slaves earned in this way, but we know that others benefited indirectly from gambling. On February 4, 1615, the slave Amarexo from Morocco died aboard the vice-flagship. His possessions were sold in El Puerto de Santa María for 70 reales, and the paymaster kept a complete list of them, a unique precaution that shows us in detail what the slave had owned at his death. Two old wooden boxes, which he must have stored under his bench, contained 30 small collars of heavy cloth, 24 pairs of cotton stockings and 6 of woolen ones, 3 pouches containing 36 small combs, 8 pairs of saddlebags, 2 knives, 4 wooden spoons, and 6 dozen decks of Barcelona playing cards. ${ }^{25}$

Amarexo had clearly filled his own little "cargo hold," and (knives and spoons aside) his seventy-two decks of cards suggest that gambling was a popular business. He also owned an unusual number of stockings. Pantero Pantera, the captain of a papal galley, wrote that "there is no lack of men among the crew who work at making stockings, nightshirts (camisciole), dice, toothpicks (stecchi), and such things, with which they obtain some money and help themselves greatly, supplementing their small provision of biscuit and water"; perhaps Amarexo had bought his items from more industrious shipmates. ${ }^{126}$ He might have obtained all the combs in port or, more likely, by haggling with the small boats that gathered around whenever a galley dropped anchor. We know that such exchanges were common and that Gian Andrea Doria was even asked to forbid them as "harmful to the crews, who barter with ship's biscuit and their own clothing, at great prejudice to themselves ... since convicts and slaves end up thin and stricken with diseases." 127 But the case of Amarexo from Morocco shows that the practice was not always harmful, because some

\footnotetext{
123 AGs, GyM, 539: letter from Tomás de Aguirre, Santander, 27 January 1599.

124 Marchena Giménez, "Vida y los hombres," 440.

125 AGS, CMC, 3 a Época, 2940-41.

126 Pantera, Armata navale, 134.

127 ADP, scaffale 70, busta 25, interno 5: Particulars of the Galleys of Naples by Gian Andrea Doria, 6 July 1587.
} 
rowers could profit from this sort of buying and selling. It also shatters some of our stereotypes about the extreme poverty of these men and their lack of living space-this slave managed to store a great deal under his bench. With a little initiative some of the ill effects of life on board could be overcome.

All these examples show that in studying economic activity in the squadrons we need to consider this kind of small commerce among crew members. Though we cannot calculate its full impact, it was obviously an important counterweight to periodic scarcities of rations, and it added a degree of cross-cultural trade and sociability to life aboard ship. Elsewhere we have studied the case of Hamete, a Morisco from the royal galley who had set up "a little tobacco shop" on board. He extended credit to Christians only if they forswore insulting the prophet Muhammad, but once he had a dose of his own medicine: a convict, Pedro de Montes, won at cards and invited his shipmates to a drink of wine if they would renounce Muhammad, giving offense to Hamete and resulting in a harsh exhange of words..$^{28}$

These cases show how galley slaves (like domestic ones), once their work was finished, could engage in trade, save money, and buy their freedom. Aurelia Martín has shown that in many notarial documents of the time, what looks like the freeing of a domestic slave for motives of conscience or friendship actually masks a previous payment by the slave out of savings from his or her labor. ${ }^{129}$ Likewise in the galleys, behind records of manumission for reasons of age or illness may lie payments for the slave's assessed price or an exchange for another slave of equal value.

It is also notable that nine years' worth of accounts show only one instance of a slave released in exchange for a Christian captive. We cannot be sure that the records are reliable on this point; every ledger does not show every category, and some ransoms were never noted down. In 1611, Philip III decreed a fine of 200 ducats for any galley officer who freed a slave without permission, but the order must not have been generally obeyed, for it was reissued in $1617 \cdot{ }^{130} \mathrm{In}$ that year, Catalina Gallardo was allowed to replace the slave Lorenzo Abraham from the San Martin with another in order to exchange him for her husband, Blas González, a captive in Algiers; but the transaction does not figure in the account books. ${ }^{131}$ There is likewise no record of Pedro Mulato, a slave whom the licenciate Cuerda had sold to the galleys in 16or; in 1617, Cuerda took him

128 Lomas Cortés and Benítez Sánchez-Blanco, "Seconde Inquisition," 83-84.

129 Martín Casares, "Repensar."

130 AGs, GyM, 820: La Junta de Galeras, 30 May 1617.

131 AGS, GyM, 820: Antonio de Aróztegui, 14 April 1617. 
back in exchange for another. ${ }^{132}$ Just in the period 1617-19, we know that in 1619 the Duke of Maqueda, governor of Oran, received two rowers from the royal galley, Mahomete Ben Buxareb and Mohamete Ben Azen, by exchanging them for two others. ${ }^{133}$ Napoleon Canoli, captain of the San Jorge, asked permission in 1607 to exchange one of his rowers, Mustafá from Algiers, for another slave in order to free his brother, who had been a captive since $1598 ;{ }^{134}$ on October 22,1608 , the Council of War agreed, but again the operation is absent from the paymaster's books. ${ }^{135}$

We must realize, then, that the number of slaves ransomed from the galleys was greater than that registered in the accounts, and that some ransoms must have been managed illegally. The average of one documented ransom per year is certainly too low and should be raised, though cautiously. It was still rare to be freed from the galleys in this way (as infrequent as the sale of old and damaged slaves), even if the records were being manipulated. Still, we see that galley officers maintained contacts with North Africa by negotiating some ransoms, and that slaves were not wholly isolated on their rowing benches. They, like other members of the crew, could sustain some relationships with the opposite shore.

\subsection{Purchase of North African Wheat and Control of Maritime Trade}

Like many coastal cities of Castile and Aragon, the Galleys of Spain sometimes imported wheat from North Africa to feed their crews. They did so only on certain occasions, because a number of factors had to align in their favor. Oran was the only fortified port on the coast with a production large enough to satisfy the demand, so purchases could be made only when there was a sufficient harvest and prices were competitive; that happened only a few times in the early seventeenth century, however, and in that period the fleet actually took more grain to Oran than from it. ${ }^{136}$ At the same time, the squadron's purveyor had an ample team of commissioners who traveled around Castile assessing harvests and grain prices. Only when crops had been underestimated, or an attack was being organized that required more provisions, would the fleet buy wheat from merchants in Oran.

Beatriz Alonso has shown that in the late sixteenth century the monarchy tried and failed to involve Oran more closely in the normal supplying of the

\footnotetext{
132 AGS, GyM, 820: Philip III to Emmanuel Filibert of Savoy, 13 February 1617.

133 AGs, GyM, 846: Consulta del Consejo de Guerra, 28 July 1619.

134 AGs, GyM, 677, fol. 681 .

135 AGs, GyM, 689, fol. 248.

136 Lomas Cortés, "Galeras de aprovisionamiento."
} 
Galleys of Spain and the armada. In 1597 the squadron's paymaster, Juan Pascual, ${ }^{137}$ signed a contract to import up to 70,000 fanegas of wheat, and a year later he signed another for 100,000 more. But the first order was very difficult to fill and the second almost impossible, since it threatened the town's own supplies. ${ }^{138}$ Perhaps for that reason, in 1599, when Philip III's visit to Valencia was being organized and the squadron asked for 8,ooo fanegas of wheat to feed its crews, ${ }^{139}$ Oran could not comply. The town delayed for so long that the fleet's purveyor, unable to wait any longer, began to buy trigo de mar ("seagoing wheat," grain sold out of the holds of other ships), although wine and other small amounts of foodstuffs were bought from Oran. ${ }^{140}$

In 16o9, after several years of bad harvests, the fleet again tried to acquire a large volume of wheat through Oran. Once more, predictions had been inaccurate and 2,00o fanegas from Cartagena had not materialized; in addition, the ships that would deport the Moriscos needed provisions. The monarchy sent 40,00o ducats to Oran for the purpose. ${ }^{141}$ Although we do not know the exact amount purchased, it is recorded that 30,000 ducats were spent and that each fanega cost between 6 and 11 ducats depending on the purchase. ${ }^{142}$ We can calculate the total amount of wheat bought at somewhere between 30,000 and 50,000 fanegas. If we add these amounts to the imports in 1597-98 and Martín Corrales's list of the import licenses of Castilian and Aragonese cities, ${ }^{143}$ we find that under the reigns of Philip II and Philip II the Galleys of Spain bought and consumed more North African wheat than any other territory under the monarchy.

To a lesser degree, wheat and other goods from North Africa entered the squadron through captures and embargoes carried out under prohibitions against trade with infidels and seizures of Christian corsair ships. Martín de Azpilcueta explained that it was right to pursue those who went to sea to rob, wound, and kill (Christian slaves who served in Muslim galliots did not count, though they were in a state of mortal sin), and in addition all merchants who shipped forbidden cargoes to Africa, whether in peace or in war, should be punished and excommunicated as if they were pirates. ${ }^{144}$ According to Miguel Ángel

\footnotetext{
137 AGs, GyM, 626, 38 .

138 Alonso Acero, Orán-Mazalquivir, 378-81.

139 AGs, CyM, 539, fol. 194.

140 AGS, CMC, 397 .

141 Ags, GyM, 726: Felipe de Porres to Philip III, 22 July 1609.

142 Ags, Estado, 213: Pedro de Toledo to Philip III, 29 October 16 og.

143 Martín Corrales, "De cómo el comercio," 151.

144 Azpilcueta, Manual de confessores, 400.
} 
de Bunes, prohibited goods were interpreted very broadly and could include not only money and weapons but also any material that could serve the Muslims in defensive or offensive war. ${ }^{145}$ Patents issued to captains general of the Galleys of Spain allowed them ample jurisdiction in cases of maritime smuggling and unlawful commerce, giving them another motive for their voyages.

We have limited information about oversight of trade with North Africa, since again only a few cases were recorded when they came to the courts' attention or caused consuls and ambassadors to complain, as happened with the corsair Venart. Here, too, as with the seizure of pirate ships, the Armada of the Ocean Sea seems to have been more active than the galleys. But at certain times under Philip III, the armada and the Galleys of Spain were joined under a single command, so that we can draw on their combined data to assess the situation more fully.

In August 1600 a settee manned by Frenchmen and loaded with leather left the Moroccan port of Salé; it was intercepted a few days later off Gibraltar by a ship of the armada, which presented its case to the Count of Santa Gadea. The settee's skipper tried to defend himself, showing papers that proved how he had conveyed a sum of money from Barcelona to one Juan de Marchena in North Africa and then loaded up with leather bound for Pisa. The count, unconvinced, immediately sentenced the crew to row in the galleys and confiscated the ship and its cargo, ordering them auctioned off for the crimes of illegal export of money and trade with infidels. But that was not the end of the suit, since Juan de Marchena, learning of the seizure, appealed to the Council of State. Marchena, a trader settled in Morocco, was in charge of ransoming captives in his area and, among other business interests, served as the monarchy's agent at the Moroccan royal court. He claimed that the money from Barcelona was intended to free captive Christians, and that in exchange for his services he had a license to trade-an example of how some merchants combined negotiating for captives with lucrative commerce in North Africa. ${ }^{146} \mathrm{On}$ that basis, he complained that Santa Gadea had taken his ship unlawfully and also had interfered with the king's business. The Duke of Medina Sidonia, who in fact was also involved in such dealings, took up Marchena's defense until, in 1603, it reached the hands of the Council of State's advisor for war.

This case offers several hints about the control that the squadrons exercised over trade with North Africa. Illegal export of money was one of the crimes most often mentioned in our records. Juan de Marchena's settee was seized

\footnotetext{
145 Bunes Ibarra, "Marco."

146 Andújar Castillo, "Rescates," 138.
} 
because Castilian reales could not be exported to Morocco, and we find a number of other such cases. In 1603 Francisco Gómez, a Portuguese, tried to cross to Morocco carrying twenty-one large sacks of reales and three small ones of escudos. ${ }^{147}$ A similar sum was involved when in 1615 the ship El Amor Verdadero, anchored in El Puerto de Santa María, resisted inspection and tried to flee. The armada pursued her and fired on her, killing several men. The boarding party found twenty-two large sacks containing the equivalent of more than 30,000 ducats in Christian and Muslim coins. ${ }^{148}$

Marchena's lawsuit casts light on Spanish interests in Morocco, much focused in those years on exploiting the special relationship that the monarchy had maintained with its ruler, Mulay al-Shaykh ("Muley Xeque") since the conquest of Portugal. ${ }^{149}$ That tie served at first to facilitate intervention in Portugal's affairs, but later turned to Spain's effort to have Morocco cede the coastal fortress of Larache; ${ }^{150}$ in both phases the Galleys of Spain acted as a privileged vehicle for the Spanish-Moroccan alliance. The linkage may have begun when Martín de Arreaga, the squadron's paymaster, was named ambassador to Morocco at the end of the sixteenth century (though he never took possession), ${ }^{151}$ and peaked in 16o9-10 during the last stage of the negotiations over Larache.

The fact is that the squadron transported much more money to Morocco than it seized from smugglers during those years. That was because in October 1609 the monarchy began to collect 200,000 ducats to finance Muley Xeque's army and compensate him for ceding Larache, ${ }^{152}$ and the galleys were charged with conveying the sum to Tangier. ${ }^{153}$ The transfer was completed in February 1610, when the Count of Elda received onto his galleys not only 84,00o ducats, 2,0oo arquebuses, and quantities of powder and arms for Muley Xeque but also the ruler himself and his court, carrying them to the fortress of Peñón de Vélez at Gibraltar. ${ }^{154}$ There, the Moroccan was received like any other ally of the monarchy, with repeated firing of artillery as he sailed into port and thirty more salutes the next day when he set foot on land. ${ }^{155}$

It is clear that the Galleys of Spain had the same kinds of economic relations with North Africa as any other territory of the monarchy; in imports of

\footnotetext{
147 AGs, Estado, 188: "Juan de Marchena," 7 January 1603.

148 Ags, GyM, 8oo: Luis Fajardo to Philip III, 12 August 1615.

149 Oliver Asín, Vida de don Felipe.

150 Mouline, Califat, 311-31.

151 AGS, GyM, 579, 139.

$15^{2}$ AGS, Estado, 219 : Duke of Lerma to the President of the Treasury, 3o October 16o9.

153 AGs, Estado, 2638, 149.

154 AGs, GyM, 739: Count of Elda to Antonio Aróztegui, 7 February 1610.

155 AGs, GyM, 743: Martín de Tausida to Philip III, 2 March 1610.
} 
wheat, and in collection of monies in Castile and Aragon to pay for the grain and finance Muley Xeque, they handled a larger volume of trade than many other areas. Though the squadron's own needs involved it in only a few ransoms of captives, it is clear that its enslaved crew members could obtain better food and clothing, and even their freedom, through their economic activity. It does not appear, however, that much income came from pursuing smugglers in North Africa, though other interests might have been at work.

Fajardo's fleet stopped at Oran on its way to attack Tunis in 16o9, and hearing of an English vessel that was conducting business in the area, set out in pursuit. But Fajardo, after capturing the ship, did not accuse and sentence the skipper but instead, learning that he knew the Bay of Tunis well, asked him to pilot his fleet; on their return, Fajardo set him free and sold him one of the ships captured in the journey for 300 ducats. ${ }^{156}$

It is something of a mystery how the royal purveyors could obtain, year after year, enough ship's biscuit for the galleys by buying "seagoing wheat" from other ships rather than from Oran; it was more expensive, but in certain years a more abundant supply. In 1606, for instance, the Duke of Medina Sidonia, who was in charge of provisioning the fleet, bought more than 5,00o fanegas of wheat in only two months at a cost of 7,00o ducats; it came from eight French and Flemish merchants, and its origin was not specified. ${ }^{157}$ Silencing the origin was more common than one might suppose. Perhaps the squadrons wished to stop dealing with merchants who traded with North Africa or came from other forbidden areas, even though those men could sometimes offer advantageous ransoms, sell them wheat, or transport grain or other necessary goods for them. In December 1598, even in the face of a severe embargo, the auditor allowed fourteen Dutch vessels to proceed to Sicily to collect the stores of wheat destined for the galleys. ${ }^{158}$ The broad jurisdictional powers of a auditor, while enforcing respect for the laws of the Catholic king, also gave him latitude to violate them in cases of both individual and collective need (as when the Dutch transports were permitted to sail).

\section{Legitimate Trade and Fraud in the Galleys}

In October 1601 Empress Maria of Austria wrote to Gian Andrea Doria. She was expecting a ship to arrive in Genoa bearing a crate of her new porcelain, and

\footnotetext{
156 Ags, GyM, 726: Luis Fajardo to Philip III, 10 September 1609.

157 AGs, GyM, 662, 210.

158 AGs, GyM, $561,76$.
} 
she asked Doria to intervene to keep it from being opened or held up in customs; rather, it should be entrusted discreetly to Cristóbal Fiertempach as soon as it was unloaded. The prince obeyed her request, and in mid-November the crate easily passed customs without inspection. ${ }^{159}$ This was not the first time that the captain general of the sea had used his influence to evade customs in favor of the Hapsburgs; in January 1599 he had resisted when the republic of Genoa sought to inspect and charge duties on the baggage of Archduke Albert and his entourage; Doria threatened to divert the ships to the port of Finale, thus damaging Genoa's image, "for it seems to me that this is not the time to care for trivial matters."160 His strategy worked, and in the end "these gentlemen [of the republic] have behaved so well that they waived not only inspection [of the baggage] but also payment of any duty."161

\subsection{Smuggling in the Galleys}

Aside from such special interventions, this type of favor was fairly common and often included an offer to transport goods securely in the galleys. Juan Fernández de Velasco, constable of Castile and governor of Milan in those years, availed himself of the service several times; in April 1600 the Galleys of Genoa brought him a crate from Naples containing thirteen decorated vases for his library, ${ }^{162}$ and in June 1602 the Galleys of Sicily shipped to him in Castile three of the four marble fireplaces that Prince Doria himself had commissioned in Genoa. ${ }^{163}$ Fernández de Velasco also used his influence over Doria to facilitate orders by his officials, as when in March 1600 he sent Doria a box containing a silver vase that Juan de Mendoza, head of the cavalry in Milan, was presenting to the king. ${ }^{164}$ In early January 1600 Doria sent one hundred "lengths of black brocade from Florence" to the Duke of Béjar, ${ }^{165}$ and on May 2 , he arranged to extract from customs - meeting some resistance this time-a writing desk for the Countess of Benavente. ${ }^{166}$

These favors continued in the succeeding years. In 16o1 Doria sent the Countess of Lemos, wife of the viceroy of Naples, a dozen chests, weighing 12 libras apiece, full of the most beautiful damasks that his sister could find in Genoa,

\footnotetext{
159 ADP, scaffale 85, busta 22: Gian Andrea Doria to Empress Maria, 16 November 1601.

160 ADP, scaffale 85, busta 18: Gian Andrea Doria to the Republic of Genoa, 24 January 1599.

161 ADP, scaffale 85, busta 18: Gian Andrea Doria to Vittoria Doria, January 1599.

162 ADP, scaffale 85, busta 22: Constable of Castile to Gian Andrea Doria, 30 April 1600.

163 ADP, scaffale 85, busta 24: Gian Andrea Doria to the Constable of Castile, 24 June 16o2.

164 ADP, scaffale 82, busta 25: Constable of Castile to Gian Andrea Doria, 27 March 16oo.

165 ADP, scaffale 82, busta 23: Pietro Serra to Gian Andrea Doria, 8 January 1600.

166 ADP, scaffale 85, busta 19: Gian Andrea Doria to Jusepe de Acuña, 3 May 1600.
} 
with a second crate containing four vases decorated with pearls. ${ }^{167} \mathrm{~A}$ year later his galleys conveyed an ornate silver bedstead as a gift to the Countess of Miranda, whose husband was influential in government, ${ }^{168}$ and the same journey may have served to ship a cargo of majolica to Juan de la Serna, the Duke of Lerma's personal secretary. ${ }^{169}$

These services and attentions were crucial to Prince Doria's economic strategy. With his rights, favors, and privileges spread throughout the kingdoms of the monarchy, he had to maintain good relations with its principal ministers; those men would assure him payment and advantageous mediation when difficulties arose in supplying the galleys, enforcing the special concessions granted him by the king, or many other jurisdictional issues, some of which arose in Genoa itself. Although Doria could normally obtain all the franchises he needed from the republic, he sometimes faced customs officials who tried to hold up the export of fresh merchandise. In July 1599, for example, a shipment of meat for the Galleys of Naples almost spoiled for that reason. ${ }^{170}$ Resistance might also come from collectors of the tax on wheat, as in January 1600 , when they told Doria that his galleys could not be exempt from duties, forcing him to appeal to the Bank of Saint George. ${ }^{171}$

These problems were repeated in every port that supplied the galleys, where there was continuous give-and-take between contracted providers and local governments. Between 1596 and 1603 alone Doria dealt with a long series of conflicts. The Camera della Sommaria in Naples sometimes demanded export fees for his supplies or blocked his privileges, as in 1603, when it demanded the return of his salary as a member of its supreme court, the Consiglio Collaterale. ${ }^{172}$ The Vicaria of Naples occasionally requisitioned his wheat or kept him from collecting his rents from the region. ${ }^{173}$ In Messina, customs men wanted to charge him four tari apiece for the almost 5,500 jars of biscuit that the Catholic fleet took on board. ${ }^{174}$ Their counterparts in Palermo filed suit in the Tribunale di Regio Patrimonio (the Sicilian equivalent of the Camera della Sommaria) because the galleys' export privileges caused excessive harm to their profits. ${ }^{175}$ And the alcalde mayor of Cartagena forbade the export of 100

\footnotetext{
167 ADP, scaffale 85, busta 20: Gian Andrea Doria to Pietro Serra, 5 January 1601.

168 ADP, scaffale 85, busta 24: Gian Andrea Doria to Francisco Tapia, 3 June 1602.

169 ADP, scaffale 85, busta 24: Gian Andrea Doria to Juan de la Serna, 10 June 1602.

170 ADP, scaffale 82, busta 21: Gio Petro to Gian Andrea Doria, 27 July 1599.

171 ADP, scaffale 82, busta 23: Pietro Serra to Gian Andrea Doria, 16 January 1600.

172 ADP, scaffale 85, busta 27: Gian Andrea Doria to the Count of Benavente, 10 October 1603.

173 ADP, scaffale 85, busta 16: Gian Andrea Doria to Philip II, 1 January 1598.

174 ADP, scaffale 82, busta 24: Marquis of Sambuca to Gian Andrea Doria, 22 November 1600.

175 ADP, scaffale 7o, busta 24: Domenico Cathaciola and Vicenzo di Lardo, Palermo, 1598.
} 
fanegas of wheat in January 1601 because they were meant for Doria's palace kitchens, not the galleys. ${ }^{176}$

Faced with this array of suits and appeals, Doria did not hesitate to use the trading privileges attached to his office to provide favors for those who could advance his business dealings, both public and private. A prominent instance was the service he provided early in the century to the viceroy of Sicily, the Duke of Maqueda. In 1600-1 the vicereine, the Duchess of Nájera, decided to arm several corsair ships and asked the prince for advice. He helped her first to purchase the vessels, later made arrangements when one of them sank, and assisted again when she sold them after her husband's death. ${ }^{177}$ In exchange for these favors, he could exert more pressure to collect on his contracts for wheat, and also to advance a long-standing suit in which he was owed payment on special concessions for royal wheat for the years 1588 and 1594; he also perceived certain back payments. ${ }^{178}$ His shipment of majolica to Serna, the Duke of Lerma's secretary, in 1602 seems to have been the return of a favor done the year before, when Serna had intervened with Lerma to release a cargo of wheat held up in Cartagena in 1601. And we can speculate that his favors to the Duchess of Lemos in 1601 were related to pressure that the Sommaria exerted on him that year about the export of some oars and spars on which he had failed to pay the necessary taxes. ${ }^{179}$ In short, he implicated viceroys, councillors, and secretaries in the profits he gained through heavy-handed use of the galleys' jurisdiction, through a protected and not always legal trade in luxury items of which he himself was the greatest beneficiary.

In the Dorias' greatest abuse of their privileges in this period, they extracted a group of Flemish tapestries from the charity hospital in Genoa and sent them to Carlo Doria, Duke of Tursi, to decorate his palace in the strada nuova; ${ }^{180}$ but that incident was not unique. In 1599 several galleys from Naples brought the prince "select grain ... wines and damasks and satin, fabrics that it might be best to pass through customs and be assigned a permit so that no problem can arise in taking them home."181 In 16oo the family evaded customs on an indeterminate amount of silk ${ }^{182}$ (an operation they repeated a year later), ${ }^{183}$ and imported a silver vase from Naples together with "other items." ${ }^{184}$

\footnotetext{
176 ADP, scaffale 85, busta 20: Gian Andrea Doria to Francisco Tapia, 13 January 1601.

177 ADP, scaffale 85, busta 21: Gian Andrea Doria to the Duchess of Nájera, 10 April 1601.

178 ADP, scaffale 82, busta 21: Angelo Paganetto to Gian Andrea Doria, 13 August 1599.

179 ADP, scaffale 85, busta 21: Gian Andrea Doria to the Count of Miranda, 19 March 1601.

180 ADP, scaffale 82, busta 23: Pietro Serra to Gian Andrea Doria, 31 January 1600.

181 ADP, scaffale 85, busta 18: Gian Andrea Doria to Pietro Serra, 1 January 1599.

182 ADP, scaffale 82, busta 23: Pietro Serra to Gian Andrea Doria, 16 January 1600.

183 ADP, scaffale 18, busta 41: Tiberio del Pezzo to Gian Andrea Doria, 6 January 1601.

184 ADP, scaffale 82, busta 23: Simone Menocchio to Gian Andrea Doria, 17 April 16oo.
} 
These regular shipments of cloth are significant in themselves. Captains general and their purveyors were great buyers of fabric, especially of the types required by the galleys. According to the purveyor Miguel de Oviedo, between January 1598 and May 1601 the Galleys of Spain acquired almost 7,ooo quintales of cord for rigging and another 56,700 varas of coarse cotton for sails and awnings. ${ }^{185}$ But beside these necessary purchases, there was also a much more luxurious trade. Just the outfitting of the royal galley that conveyed the archdukes in 1599 required the purchase of 2,200 varas of cloth of gold, 5,000 ounces of gold thread, and 5,000 varas of damask. ${ }^{186}$ Although that degree of consumption may seem unusual, in fact such sumptuary spending was fairly common in the annual outfitting of the principal galleys, the vice-flagship (called the patrona) and especially the flagship (called the capitana). In 1603, only to outfit the flagship of the Spanish squadron, the galleys bought 93 libras of Chinese silk, 55 libras of fine Moorish silk, 2 libras of red silk, 740 varas of damask, 5,500 varas of red linen, and about 4,100 varas more of different grades of cheaper wool. The order was so large that a commissioner was sent ahead six weeks earlier to inquire discreetly about prices, since merchants who saw galley officers coming would raise them in anticipation of "the great quantities" they usually bought. ${ }^{187}$ Captains general of the galleys had special access to materials like silk thanks to the convoys of vessels that arrived in Messina every year to fill their cargo holds, ${ }^{188}$ and since they also maintained a large volume of trade with many merchants, they could acquire these and other luxury fabrics on the most favorable terms.

Other officers of the squadrons, inspired by the example of their superiors (whose activities they helped to conceal), followed the same path. Martín de Quijano, sub-inspector of the Galleys of Genoa at this period, performed similar operations on a smaller scale. Though he lacked Prince Doria's prerogatives, he made up for them with ingenuity, mixing his own goods with those of distinguished travelers. In 1603, for example, he used a voyage of the two princes of Savoy to avoid paying duty on a bedstead he was shipping to Castile. ${ }^{189}$ Most of his goods traveled in small parcels, and almost all had been commissioned by family and friends. Though his correspondence is incomplete, it includes several requests for purchases, especially for items of Italian make. In 1594 Melchor de Novar asked him for a few varas of taffeta; Juan de Obregón and

\footnotetext{
185 AGs, GyM, 582, 99-10o.

186 ADP, scaffale 70 , busta 24.

187 AGs, CMC, 3 É Época, 397.

188 ADP, scaffale 85, busta 21: Gian Andrea Doria to the Grand Duke of Tuscany, 25 May 1601.

189 AGs, Galeras, 6, fols. 438-39.
} 
Pedro de Muruzábal requested garments for their relatives; Pedro de Quincoces wanted a bedspread, and Juan de Cerón a taffeta one for his own bed.190 In 1595 Gabriel Sánchez asked Quijano if he could take some baggage onto his galley when the squadron was in Barcelona ${ }^{191}$ to avoid paying customs duty, and a letter from 1603 suggests that Martín was even able to sell some taffeta at the court in Valladolid through a certain Francisco de la Serna. Many of these commissions originated in Naples, where Quijano could count on the help of an infantry captain, Rodrigo Messía de Prado. In the spring of 1603 the captain wrote him several letters describing how he sought out the best prices for wine, silk, damask, velvet, bedspreads, and hangings, at the request of both Quijano and his wife (who was his cousin, María de Quijano) and other family members. ${ }^{192}$ Some individuals must have owed him a large debt of gratitude, or valued his services highly—in 1598, when Quijano asked Guillermo Berdina to make him a ring in Milan, Berdina sent him one of his own wife's so that he would not have to wait too long. ${ }^{193}$

It is possible that not all this shipping was illegal. Although the galleys' ordinances held that, because of their reduced space, only necessary supplies could come on board and crew members could bring only their "clothing and work outfits,"194 special permission was sometimes given for ministers or merchants to ship luggage or goods if they paid the required duties. A letter from Gian Andrea Doria's administrator suggests that the prince charged 10 percent interest for conveying money between Castile and Italy, and established the required transport fees. ${ }^{195}$ Elsewhere it appears that Doria, in layovers during his journeys, would inquire if any merchandise needed to be taken onto his galleys, ${ }^{196}$ and his son Carlo Doria made similar contracts in the following decades. ${ }^{197}$

It is curious, therefore, that in one of his last letters as captain general of the sea Gian Andrea Doria reproaches Pedro de Leiva, captain general of the Galleys of Sicily, for harming the king with his "industries," that is, for using his galleys to trade in personal goods. Leiva retorted in his own defense that everyone else did the same, beginning with Doria's own son, to which the prince replied that

\footnotetext{
190 AGs, Galeras, 216, fols. 597-646.

191 AGS, Galeras, 4, fol. 108.

192 AGS, Galeras, 6, fols. 442-57.

193 AGs, Galeras, 5, fols. 297-98.

194 Marchena Giménez, "Vida y los hombres," 456.

195 ADP, scaffale 82, busta 23: Pietro Serra to Gian Andrea Doria, 8 January 1600.

196 ADP, scaffale 85, busta 21: Gian Andrea Doria to the Duke of Maqueda, 22 March 16o1.

197 San Ruperto Albert, "Emprenedors," 281-82.
} 
it could not be true, for if it were, "I would strangle him with my own hands."198 After his father's death, Carlo Doria might have seen his way clear to indulge in previously forbidden activities, but letters written only a few months after the rebuke of Pedro de Leiva indicate the opposite.

In June 1602 Carlo Doria set sail for Spain with the Galleys of Genoa. He had orders to join the rest of the fleet on the Andalusian coast to launch a new assault on Algiers, so this was no ordinary journey but an important campaign. One member of the squadron, however, was Domenico Sevo, an agent of Gian Andrea Doria's who had embarked with the sole purpose of selling merchandise at different ports. He brought silk hose, trimmings, collars, bedspreads, cloth called "Japanese" (Giapone), and a box of unspecified "stuff." He first tried to sell some in Cartagena, but the layover was too short. ${ }^{199}$ In Cádiz his luck improved - while Carlo Doria paid his respects to the Duke of Medina Sidonia, Sevo began to offer his goods in Cádiz and Seville. At least three galley skippers helped him, selling both their leader's merchandise and their own. Sevo managed to dispose of twenty-two bedspreads at 200 reales apiece, the chest of unidentified contents at 40 reales, and the collars and "Japanese" material for more than 300 reales. The decorative trimmings were harder to sell because in Seville, apparently, a more delicate type was preferred, but by August 2, just before the fleet sailed again, Sevo had realized 11,830 reales from all his merchandise. ${ }^{200}$

These letters reveal that Prince Doria not only was aware of how his skippers indulged in trade on the side but even took advantage of the fact to sell his own goods. Another question is whether these transactions fell under the galleys' legal privileges or not. Though we can only guess, it is significant that in the course of five letters Sevo never mentions any deductions for paying customs duties. It is also true that skippers did not always proceed under their leaders' protection; they also risked acting on their own, as we see from occasional cases that came before an auditor.

In 1582 a suit was brought against a captain in the Galleys of Genoa, Nicola Garibaldo. Several witnesses testified that in his latest journey to Spain he had brought on board thirty sacks "of a material that looked like earth" (it was gunpowder), saying that it was used in the manufacture of ink and that he planned to sell it in Barcelona. No word was heard of the sale, but a ship's boy in charge of cargo testified that, after returning to Genoa, Garibaldo had asked him to

198 ADP, scaffale 85, busta 22: Gian Andrea Doria to Baltasar de Zúñiga, 2o September 1601.

199 ADP, scaffale 82, busta 27: Domenico Sevo to Gian Andrea Doria, 6 July 1602.

200 ADP, scaffale 82, busta 27: Domenico Sevo to Gian Andrea Doria, 27 July and 2 August 1602 . 
keep twelve small sacks containing 12,00o reales in silver. Once unloaded, the galley sailed to Sardinia, and though no suspicious goods had been taken aboard before the voyage, on its return trip the skipper had stored eighty-three sacks of grain and one hundred cheeses in the hold; back in Genoa, he unloaded them into small boats under cover of night.

The galley's yeoman of the hold provided more information. The skipper had ordered him to hide fifty-six bales of cloth, some of them silk, under the ship's biscuit, and he knew that other quantities were hidden elsewhere. He had also heard his captain arranging with a scribe to sell the cloth to several Barcelona merchants at 1 escudo per bale, and he further claimed that the captain had brought a large sum of money aboard in sacks that "weighed as much as a man could lift" (600,00o reales and 40,00o gold escudos) and came from a Genoese merchant whose name he did not know but who had paid 4 percent interest on the delivery. ${ }^{201}$

If Doria sued Garibaldo, it was surely because he had gone too far and damaged the prince's own interests. We need only compare the percentage that the skipper supposedly negotiated for transporting the money with the percentage the prince demanded. In any event, his activities show that skippers of galleys, in addition to their official duties, acted by the same logic as any private merchant captain - they tried to avoid traveling with an empty hold and seized on any voyage to load whatever goods they could, on their own or others' behalf. They could usually assume the protection of the squadron's legal jurisdiction.

Other crew members indulged in the same practices. In October 1604 the auditor of the Galleys of Spain demanded that the corregidor of El Puerto de Santa María hand over three soldiers from the squadron, arrested as they tried to introduce counterfeit coin on the coast near Santa Catalina. ${ }^{202}$ We recall that chapter 10 of the ordinances of the papal galleys forbade the adulteration and counterfeiting of coins in the galleys and the possession of any tools for doing so. ${ }^{203}$ Only a few such cases are documented, but we have few records from appeals courts of the galleys, whether about counterfeit coin or, especially, the illegal export of money. For that we can look to different sources, such as chapter 11 of the license granted to the Duke of Lerma for the governance of his galleys in 1616. The provision mentions the great harm caused to the royal treasury by exporting money without a license, and demands that "in the squadron of Denia there not be loaded nor taken from these kingdoms any money from any person, church, monastery, hospital, council, or university,

\footnotetext{
201 ADP, scaffale 70, busta 25, interno 17.

202 ADP, Puerto de Santa María, 9, pieza 29.

203 ASv, Miscelanea Armadi, 54, fol. 85.
} 
[nor] in any way and for any purpose ... there be taken away or loaded ... any merchandise or contraband ... without having paid the proper duties in the ports." ${ }^{204}$ Perhaps the members of the Council of War still remembered the scandal from two years before, when the silk that had vanished from the Indies fleet turned up on the galley Santa María; ${ }^{205}$ there might also be an echo of the charges brought against captains of the squadron in 1608 for having stolen part of the rations for their own crews. And there had also been the uproar over the Visit of 1591.

\subsection{The Visit of 1591}

The greatest form of corruption in the galleys was not the occasional evasion of customs duties on luxury products, manufactured goods, and fabrics, or the theft of modest amounts of gunpowder by skippers and soldiers. Far more serious was the systematic siphoning off of money from the squadrons' budgets. This type of fraud affected the king's purse most directly, and any crew member might indulge in it to some degree. But it was the financial officers-the squadron members in charge of administering allowances, buying supplies, and distributing them among the ships-who could most easily exploit for their own benefit the economic privileges granted by the king, thanks to the enormous volume of goods they dealt in and the breadth of their client networks. Suspicions about long-standing corruption in the Galleys of Spain led Philip II in 1591 to order the licenciate Juan de Acuña to visit the squadron and report on possible offenses against the royal treasury.

Inspector Acuña wasted no time. Within a few months after his arrival in El Puerto de Santa María, almost every great name associated with the logistical and financial management of the squadrons in those years was confined in chains, accused of stealing from the king's treasury. These included the pursers Tomás de Aguirre and Martín de Durango, the quartermasters Pedro López León and Miguel de Zufre, the purveyor Juan Sáenz de Oyanguren, the paymasters Juan Ortiz de Zárate and Pedro de Quincoces, the inspector Íñigo de Lezama, and the sub-inspector Martín de Quijano himself, together with a few scribes.

204 "[En la] dicha squadra de Denia no se embarque ni saque destos reinos dinero alguno de ninguna persona, iglesia, monasterio, ospital, concejo ni universidad [y que] con ningún color ni para ningún efecto ... se saque ni meta ... mercaderías ni cosas de contrabando, ... sin haver pagado los derechos que devieren en los puertos." AGs, Estado, 1945: "Licencia al duque de Lerma para armar quatro galeras."

205 AGs, GyM, 795: Emmanuel Filibert of Savoy to Philip III, 21 June 1614. 
All were accused of serious crimes, the worst having been committed by agents who bought and stored supplies for the squadron. Juan Sáenz de Oyanguren, its purveyor for the coast of Andalusia, was said to have developed a whole network of providers who, in connivance with him, presented invoices that were false or padded with dubious goods and services. The network extended to several ports but was centered on Gibraltar, and several witnesses told Acuña that its members belonged to different professions. There were agents for wine, who researched prices and bought wine for the squadron from private sellers; bakers, accused of cheating the Crown by altering weights and measures of the wheat they received for making the essential ship's biscuit; butchers, who cut underweight portions of fresh meat; traders in cloth and cord, denounced for not having provided full complements of rigging and sails; and other suppliers of coarse wool, tow, suet, and even foods for the sick like chickens, eggs, and sugar. Gonzalo Rodríguez presented a special case. The squadron had no forge of its own in Gibraltar, and Rodríguez was the only blacksmith able to supply the tools, chains, and nails that the galleys needed, so Sáenz had employed him on several occasions. But it was suspected that he had charged for many orders that he had never filled, and it was rumored in the town that he boasted about all the money he was earning, enough that he could soon "reward himself" by buying a vineyard.

Sáenz's possible cheating, however, paled in comparison to that of Miguel de Zufre, a quartermaster in Cádiz. This official, who was in charge of the squadron's storage facilities, practiced a surprising array of deceits to keep part of the supplies for himself. The most common was to remove wheat from its sacks and replace it with rocks and sand. When asked to supply a certain amount of grain, he would declare some of it spoiled and unusable and have those sacks thrown into the sea; but his slaves were told to dispose of the sacks of rocks and sand instead. Each time this happened, Zufre was left with several quintales of grain to distribute among his partners in crime. He did likewise with wine, cheese, and chickpeas, which he later auctioned off in the city.

Miguel de Zufre had even more tricks up his sleeve. According to his trial records, he also cheated with grain in collusion with skippers who shipped it in their galleys, and that crime could be proven. The prosecutor Diego de Barrena showed that in 1588 and 1589 alone, Zufre and his nephew had appropriated almost 8,500 fanegas of wheat from trade with Sicily and Oran. His method was very simple: when ships whose captains conspired with him entered port, they would declare with the help of a scribal accomplice that part of the cargo had been soaked during the voyage and was now useless. Then they either sold the wheat to foreign merchants in the same town or, helped by the paymaster 
Pedro de Quincoces, loaded it onto small boats and sold it at different points along the coast.

Not only grain brought into the galleys was manipulated in this way, but also grain that was to go out. Instead of claiming that wheat had been spoiled by soaking, the captains would falsify the capacity of their holds, pretending to transport much more than they actually carried. Zufre, helped by, among others, a renegade skipper named Joan Marroquín, who shipped supplies to Tangier, in just two trips to that fortified port had made 1,40o fanegas of wheat disappear, though the total was assumed to be much greater. He fell back on other deceptions as well, beside the well-known practice of altering the weight and volume of wheat taken from the storehouses. A French baker, Xacome Duarte, once helped him to sell 4,00o fanegas on the private market, after which they split the profits. Large amounts of grain were spirited out of storage at night without leaving any trace in the accounts, and Zufre even managed to sell significant quantities of mazamorra, the crumbs of ship's biscuit that remained at the bottom of sacks.

Zufre's actions became so brazen that after Francis Drake's attack on Cádiz in 1587 he claimed that the pirate had burned 3,450 quintales of biscuit, 3,26o fanegas of wheat, and almost 400 casks of stored wine, all of which, in fact, he had stolen and sold himself. In the end, he was tried on nineteen charges, accused of having defrauded the Crown between 1587 and 1589 of 3,750 quintales of wheat, 17 quintales of gunpowder, 20 quintales of cheese, and the abovementioned casks of wine.

Captains and skippers of galleys were usually accused of smaller frauds, along the lines of the smuggling we saw above. Captain Juan Marín's offense, for instance, was to conceal 100 quintales of biscuit out of a shipment of 400 , in collusion with the inspector Íñigo de Lezama and the purser López de Zárate. He had also lied when he claimed to have received from Zufre and the purser Aguirre 1,00o varas of coarse cloth and 50 quintales of suet for his galley; those goods had never existed, but, in exchange for the favor, the officials had raised his salary twice in a single year. He does not seem to have made distributions honestly, either. Depending on the circumstances, he appropriated or concealed supplies intended for his squadron and sometimes sold them to his galley's crewmen, sharing the profits with his collaborators.

The findings of the Visit of 1591 did not reflect the severity of the crimes it uncovered, in part because in the course of the trial some of Acuña's own associates were found to be cheating. Someone who had access to them was taking messages to the accused prisoners (three notes, including one written in invisible ink, were found in Miguel de Zufre's possession), and a nun from the Espíritu Santo convent in El Puerto was helping them to communicate with 
the outside. Those letters went to Alonso de Rosales and often concealed coins (one contained a doubloon worth 4 escudos). Rosales would then order the scribe of Acuña's commission to hasten the proceedings, or he informed the prisoners if they were going to be tortured and later reported on the results. ${ }^{206}$ Until his interference was detected, he was probably able to influence the nature of some sentences, though most of them were merely fines.

Juan Sáenz de Oyanguren, after paying his fine, kept his position and years later, in 1610, became an inspector himself, reviewing the accounts of the paymaster Fernández de Villegas. ${ }^{207}$ López de Zárate entered Doria's service and in the following years kept the prince informed of the state of his affairs in Italy, particularly in Naples. ${ }^{208}$ Tomás de Aguirre, after a stretch in the Galleys of Flanders, resumed the post of purser to the Spanish squadron and occupied it for many years. ${ }^{209}$ Martín de Durango remained in his original purser's office, completing forty-two years of service there in $1600 .{ }^{210}$ And Miguel de Zufre not only kept his job but soon afterward arranged the appointment of his son Juan as treasurer and quartermaster of Cartagena. ${ }^{211}$ In the end, the only significant action that emerged from the Visit of 1591 was the reformed model of management for the squadron introduced in $1592 .{ }^{212}$ We should look more closely into the reasons for this relative indifference.

Daniel Dessert explained years ago how the French navy under Louis XIV was maintained in part thanks to a series of families whose members specialized in its administration for generations. Passing on their experience from father to son, they were experts in the logistical and human problems of the enterprise and knew how to handle them efficiently. Blood and kinship became the key to naval management while direct or collateral family ties dominated the profession, making it almost impossible for an outsider to rise through his own merits. ${ }^{213}$

There is no doubt that the purveyors, paymasters, and pursers of the Spanish fleets shared this characteristic with their French counterparts. The great families involved in financial management of the galleys from the late sixteenth to the early seventeenth centuries - the Quijanos, Adanas, Obregóns, Zufres, and

\footnotetext{
206 AHN, Consejos, 41409.

207 AGs, GyM, 742: Juan Sáenz to Juan de Ciriza, 5 December 1610.

208 ADP, scaffale 82, busta 24: Juan López de Zárate to Gian Andrea Doria, 2 August 1600.

209 AGs, GyM, 975: Tomás de Aguirre to Philip III, 21 June 1614.

210 AGS, GyM, 576, 210.

211 AGs, Galeras, 6, fols. 436-37.

212 Molina Heredia, "Galeras," 6o5.

213 Dessert, Royale, 48-56.
} 
Alarcóns - were related to each other, and Martín de Quijano's letters before and after the Visit of 1591 reveal the internal solidarity that helped them escape punishment. ${ }^{214}$ It is equally clear that the monarchy, though it could control them to some degree and had the means to pursue their corrupt practices, was inclined to pardon them, in part because it could not replace them, and in part because the success of naval operations depended to some extent on their efficiency. The power that these officials held over the crews could be decisive at crucial moments, and their personal credit, based on favors to merchants (whether licit or fraudulent), was essential to the ultimate goal of keeping the galleys in good working order, as we shall see in the next chapter.

\subsection{The Galleys of Spain and El Puerto de Santa María}

To grasp the full extent of the influence of these suppliers and other officers of the galleys we must analyze their impact on economic activity along the coast, though that is not easy to do. Because the galleys were so mobile and consumed resources so quickly, a squadron in the course of a year would make purchases at a large number of ports; to draw a map of their client and trade networks and assess the tensions generated by their jurisdiction, we would have to compare each unit's accounts with municipal ones, which are scattered and have not always survived. One place to start, however, is the town of El Puerto de Santa María. Located on lands belonging to the Duke of Medinaceli at the mouth of the Guadalete River (a strategic site near the Gulf of Cádiz, the Jerez wine region, and the commercial emporium of Seville), it became, after the Battle of Lepanto, the home port for the Galleys of Spain.

Our first references to the impact on the town of the squadron's arrival come from 1577. In March of that year its corregidor wrote a report setting forth the chief complaints that the Duke of Medinaceli's magistrates would make against the galleys' jurisdiction from that date and throughout the seventeenth century. Their main tenor was to denounce the continual erosion of the duke's rights caused by the galleys' commercial privileges, whether employed legally or illegally. ${ }^{215}$ By comparing those privileges with contemporary account books we can trace the boundaries of this economic relationship.

One of the corregidores' main accusations against the galleys was that they made the town lose sales taxes on meat and wine, though the situation was different for each of those products. The galleys did not consume large amounts of fresh meat, since it was hard to preserve on board, and meat did

214 Lomas Cortés, "Patronazgo."

215 ADM, PSM, 6, pieza 66. 
not even represent a large part of the duke's income; therefore, the conflict about it reflects the abuses committed by galley officers with special clarity. Each squadron was allowed to designate one butcher shop for its supplies and buy its products free of sales tax. ${ }^{216}$ In El Puerto de Santa María that "shop" was a wooden structure on the riverbank, where the galleys had their meat killed, cut, weighed, and sold — especially beef and veal, together with by-products like leather, lard, and soap. Local officials complained that the business was not only supplying meat for the crews but also selling it to local residents and outsiders, while its lower prices caused unfair competition to the town's other butchers, some of whom even bought there themselves. At the same time, it diminished the duke's income.

Records of two lawsuits from 1581 and 1593, brought by the corregidor and the treasurer of El Puerto's customhouse, provide a clear picture of the problem. The galleys' butcher shop sold meat openly not only to ships' crews but also to anyone who wished to buy it, both on the riverbank and inside the town. It was common to see "Moors from the galleys selling in this town small amounts of mutton and beef, as well as tuna and many other products like soap"-perhaps another way that slaves could acquire funds through petty commerce. Nor was it unusual to find soldiers "in a public street of this city [with] a large basket ... in which was ... a dead pig missing one leg, and the soldiers were weighing out the meat for certain persons," while "in the square by the forge ... there was a galley skipper sharing out a pig, as at other times ... [and] he distributed it publicly there without ceremony" and without paying the required taxes. While that meat had been bought in ways that cheated the royal treasury, according to one witness things were even worse, in that many animals had been stolen from local farmers as they drove their herds along the roads, so that some were now refusing to pass near the town. ${ }^{217}$

It is unsurprising, then, that the Duke of Medinaceli made constant demands to have the butchering structure on the riverbank torn down. It appears to have been partly demolished before 1593, but the Count of Santa Gadeathough he was related to the duke, according to Molina Heredia ${ }^{218}$ - had it built up again, upon which the customs treasurer, in December of that year, demanded its removal for violating the town's right to collect three different kinds of taxes (alcabala, sisa, and millones). ${ }^{219}$ The attempt seems to have failed, because in 1617 the Council of War was again asked to order the building

\footnotetext{
216 Sirago, "Flotta napoletana," 111-72.

217 ADM, PSM, 7, pieza 18; ADM, PSM, 8, pieza 14.

218 Molina Heredia, "Galeras," 6oo.

219 ADM, PSM 8, pieza 16.
} 
taken down. ${ }^{220}$ This time it was argued that its position interfered with the loading and unloading of goods at the port, and a royal decree demanded that the duke's taxation privileges be respected, but the squadron's purser, after "taking [the order] in his hand, kissing it, and pressing it to his forehead with proper respect," proceeded to ignore it entirely. ${ }^{221}$

Aside from the "shop's" inconvenient location (and it seemed not to have moved by 1664), ${ }^{222}$ what the Duke of Medinaceli really wanted was for the squadron to pay at least some tax, which was very difficult to achieve. In the early years he fought to impose the usual to percent duty, arguing that sales to private individuals were not exempt; ${ }^{223}$ by 1594 he was trying for only 5 percent. ${ }^{224}$ When even that proved impossible, in 1597 his efforts turned to keeping watch over the butchers who bought meat, hides, suet, lard, offal, and other products illegally from the squadron's "shop" and later sold them;; 25 but repeated references to this cheating in subsequent decades suggests that it was never wholly eliminated.226

Because the squadron's account books dealt with other matters beside these supplies, it is difficult to verify these accusations of fraud. But we do know that although butchers in El Puerto provided meat to the galleys only occasionally, there were other merchants who did so regularly and in great quantities. In these cases the purveyor would buy all the meat for one year from a single seller, so that the privilege was in effect leased out, unlike the case with other products. In 1605 the official supplier became Cristóbal de Ledesma, ${ }^{227}$ in 1606 Leonardo Curtis, and in 1607 Juan Pérez. Pérez, in a single year, sold 14,6oo libras of meat to the galleys in eighteen deliveries, earning more than 1,00o ducats. At the same period, he became one of the main beneficiaries of the sale of biscuit fragments, mazamorra; one of the few products that the galleys were legally entitled to sell, they were often used to feed cattle. We wonder, therefore, if there was some kind of reciprocal arrangement between these suppliers and the galleys, which also helped to stock the "butcher shop" with fresh meat. ${ }^{228}$ We would need to compare this information with the rations of meat destined for crew members that year, to see if purchases included an oversupply that

\footnotetext{
220 AGS, GyM, 823: Consulta del Consejo de Estado, 10 November 1617.

221 ADM, PSM 9, pieza 46.

222 ADM, PSM 9, pieza 43.

223 ADM, PSM 6, pieza 45 .

224 ADM, PSM 7, pieza 64.

225 ADM, PSM 9, pieza 22.

226 ADM, PSM 9, pieza 43.

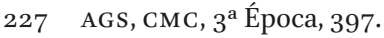

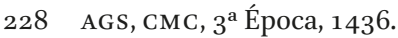


could later be sold; but, in the absence of such a comparison, we cannot come to any conclusion.

Something similar happened with supplies of fish. The account books register only purchases of cod in season, almost always from foreign ships that were passing through. But as we mentioned above, witnesses complaining about illegal sales of meat in El Puerto also said that galley slaves sold tuna; this puts us on the trail of another suit against the squadron for usurping income owed to the duke. In April 1582 his chief agent claimed that his master's income from duties on fishing had collapsed. Before the galleys had made El Puerto their home, many local boats had taken tuna and other fish and sold it in the town (at one point there had been forty shallops in the fleet). But that was now a thing of the past; many boats had been abandoned, and families that had once lived by fishing were ruined. An investigation was opened, and the resulting trial provided important information. According to witnesses, the collapse had begun six years before, when officers of the galleys had begun to send their own boats out to fish, protected by the squadron's privileges. At the same time, they often seized cargoes of fish from their competitors, giving the crews' needs as their excuse. Altogether they had destroyed almost all incentive to fish, though some offered townspeople a chance to continue fishing as long as they sold their catch to the galleys.

If we are to believe the duke's representatives, the squadron had set up the business very well for its own advantage. The paymaster Pedro de Quincoces and the pursers Francisco de Arriola and Martín de Durango (all of whom would be accused in the Visit of 1591) enrolled local fishermen as soldiers or sailors in the fleet while employing them in their private fishing boats. (Quincoces owned two shallops and Arriola and Durango three each, while others belonged to skippers.) In this way, local men could continue to fish, though with one new condition - they now enjoyed the same privileges as the galleys and no longer had to pay sales taxes to the duke, nor could their catch be seized. Meanwhile, the officers kept part of the profits together with the salaries and rations of those new "crewmen" of the squadron (i.e., the local residents). The other fishermen of the town could not compete in this situation; the fraud had increased the price of an arroba of fish from 9 to 20 reales. This practice, according to the duke's agent, harmed not only the "republic of citizens" but also the royal armadas, which now had to pay more for fish and also had crew members falsely enrolled on their books. ${ }^{229}$

229 ADM, PSM 7, pieza 15. 
The most harmful fraud against the Duke of Medinaceli's rights actually had to do not with meat or fish but with wine. A report by the corregidor calculated that between 1584 and 1590 the galleys' purveyor had bought from townspeople of El Puerto more than 112,300 arrobas of wine (slightly over 16,000 a year), of which only one-fourth had been declared to customs. ${ }^{230}$ This uncontrolled commerce diminished the duke's revenues, but above all it kept him from exploiting fully the tremendous potential of shipping wine from his vineyards to the Indies. At the end of the sixteenth century, El Puerto de Santa María had more than 180 taverns, thanks to its strategic location at the mouth of the Gulf of Cádiz, from which sherry, the prized wine of Jerez, was exported. ${ }^{231}$ It was said that the Duke of Medina Sidonia, by selling his casks of wine by that route, brought in double what they would have earned in Andalusia. But, as a report in 1592 made clear, Medinaceli's attempts to do the same was thwarted by the dealings of the galley's captain general and financial officers. The Count of Santa Gadea himself had stolen a march on the duke, "load[ing] one or two ships every year at his own risk with wine and other goods for the Indies" and benefiting from his jurisdiction within that enclave. ${ }^{232}$

The squadron's ledgers reveal to what extent El Puerto's manpower and wealth depended on trade in wine. In 1603 alone (a normal year without major campaigns), the squadron bought 7,800 arrobas of wine from more than fifty residents; ${ }^{233}$ these figures accord well with the complaint registered in 1590 if we remember that at that date the Galleys of Spain consisted of about thirty vessels but had only eleven left at the beginning of the seventeenth century. It is unsurprising, then, that in those years income from brokers who sought out wine for the galleys increased dramatically, while the duke's men saw the expansion of that profession as aggravating the problem-both townspeople and outsiders "bribe them [the brokers] very well to conceal their sales ... and the truth rarely comes to light." As a result, there were "many frauds and deceits that the brokers carry out ... with the king's ministers who come to them with their deals and schemes ... which is very inconvenient for the treasury." It seems that townspeople hid their harvests in their cellars when prices went down and pretended that officers of the galleys had bought them, so that the duke's goal was "to keep the king's ministers from making agreements ... for they buy everything on offer by saying it is for his Majesty, and though it is obviously done for the sake of their deals and schemes that is impossible to

\footnotetext{
230 ADM, PSM 7, pieza 19.

231 ADM, PSM 7, pieza 64.

232 ADM, PSM 7, pieza 76.

233 AGs, CMC, 3 Época, 397.
} 
prove; and with this they [residents] do not pay tax on what they sell, for they say it is on orders from his Majesty." The duke's side demanded of the court that at the end of each harvest a registry and inventory be made of every house and storeroom in the town, and that early in each year the squadron communicate to the corregidor the amount of wine it planned to buy; further, that the magistrate of El Puerto be present at each transaction to oversee prices and amounts, even those legally free of tax, as a way of palliating "the greed of the king's ministers, which increases daily."234

Medinaceli obtained a warrant from the treasury that ordered the squadron's purveyor to declare every purchase made in El Puerto, but it did not help much. At the close of the sixteenth century, the licenciate Tomás de Angulo proved that wine was still being sold illegally to galley officers. In a trial of eighteen town residents, he showed that at least 1,720 arrobas of wine had been sold to different members of the squadron without prior declaration or payment of the required taxes. ${ }^{235}$ It began to be common, therefore, that instructions issued to El Puerto's chief treasurers and scribes include a reminder that financial officers of the galleys should be pressured every year to allow inspection of their ledgers, so that those could be reconciled with customs records. $^{236}$ The effort yielded few results, however, as the officers continued to avoid cooperating. ${ }^{237}$

There seems little to support the accusations, repeated throughout those years, that embargoes by the galleys, purchases on credit, and delayed payments of debts were bankrupting producers of wine. ${ }^{238}$ On the contrary, it appears that, as with meat and fish, townspeople took advantage of the galleys' jurisdiction, especially their officers' exemption from paying "tributes, tolls, or any other duty on the provisions and supplies and other things that they buy for them, nor are those who sell to them required to pay them."239 Residents could avoid those taxes as well, creating a lucrative business between themselves and the galleys, with the connivance of customs officers and to the detriment of the duke's income. A complaint in $1581,{ }^{240}$ and an accusation in 1586 by Seville's chief scribe against El Puerto's head magistrate and some of its councillors, charged them with exporting wheat and biscuit illegally without

\footnotetext{
234 ADM, PSM 8, pieza 15.

235 ADM, PSM 8, pieza 13.

236 ADM, PSM 9, pieza 22.

237 ADM, PSM 8, pieza 5.

238 ADM, PSM 8, pieza 5 .

239 ADM, PSM 8, pieza 9.

240 ADM, PSM 7, pieza 2.
} 
the proper registration or permit. ${ }^{241}$ We find two familiar names among the customs officers in 1593: Juan Mosquera Figueroa (doubtless a relative of the squadron's auditor) as executor, and Joan Marroquí, the skipper who had helped Cádiz's quartermaster steal wheat from North Africa, as the collector of pilotage fees. ${ }^{242}$

This last detail is revealing. The Duke of Medinaceli complained that aside from usurping his sales taxes, the squadron harmed maritime traffic in El Puerto by engaging in pilotage, the system of towing ships across the mouth of the Guadalete River. We have no data on the history of this concession, but in 1579 its owners sued because the arrival of the galleys had diminished their income. An original sum of 46 o ducats a year had dwindled to only about 70 ducats, ${ }^{243}$ largely through interference by the galleys, which piloted their own vessels. Aside from this unfair competition, "for fear of them [the galleys] ships avoid this port and go to others, because [the galleys] regularly steal rigging and sailors from them and do other damage, the greatest and most inconvenient of which [is] the general embargoes of ships ... because foreigners do not come so as not to be embargoed ... and locals cannot sell their products."244

Although the embargoes could be harmful and off-putting, it is only fair to recall how much business derived from provisioning the galleys. Between June 1602 and August 1603, for example, the squadron's paymaster registered a total of no fewer than forty-two shipments, of which at least twenty were handled by skippers from El Puerto de Santa María. Most involved short journeys that connected the squadron to suppliers in Sanlúcar, Seville, or Las Aceñas de la Cartuja, where a bakery made most of the ships' biscuit. These vessels carried wheat, artillery, gunpowder, money, wood, and wine. In addition, there was the work of loading and unloading, transportation to warehouses, and, above all, the products bought directly from local residents. ${ }^{245}$

Although most of the duke's complaints involved trade in meat and wine, the galleys' purveyor maintained close, stable commercial relations with many men and women of El Puerto. The squadron was an important client of the local bakeries and often ordered large quantities of biscuit. In 16o8, seven bakers

\footnotetext{
241 ADM, PSM 7, pieza 22.

242 ADM, PSM 8, pieza 19.

243 ADM, PSM 7, pieza 8.

244 " $[\mathrm{P}]$ or temor dellas dexan de benir navíos al puerto y ban a otros, porque de hordinario les toman xarcias y marineros, y hacen otros daños, [siendo] los envargos generales de navíos ... el mayor ynconveniente de todos, ... porque no bienen los estranjeros por no ser envargados, ... y no pueden vender sus frutos los vecinos." ADM, PSM 7, pieza 31. 
agreed to produce 6,150 quintales at a price of 97,000 reales, and year after year the bakery owned by Alonso de Luna and Alonso Martín billed the squadron for thousands of ducats. They were not alone. A shoemaker, Juan de Jaén, made hundreds of shoes every year for the rowers, ${ }^{246}$ and a cooper, Sebastián Rodríguez, sold thousands of barrel hoops (6,ooo between 1603 and 1605). The commonest contracts in the ledgers are for small but very frequent transactions with all sorts of providers: scribes, landlords, haberdashers, dyers, wineskin makers, blacksmiths, carpenters, woodcutters, weavers of esparto grass and wicker, locksmiths, haulers, silversmiths, and even a few painters and sculptors who decorated ships' figureheads and flags. Altogether, they numbered about 150 in a population of slightly over a thousand. (There might have been more, but the books often omit the seller's origin or the details of a sale to more than one person. $)^{247}$ Much of the business of El Puerto de Santa María was obviously done with the galleys, a fact that could result in tensions over jurisdiction.

The Duke of Medinaceli had two principal aims, to control the sale of wine and to avoid embargoes. He always instructed his agents to maintain "friendship and good relations" with the captains general of the galleys, their purveyors, and "persons close to them ... because in this way and with a little cleverness many [problems] will be lessened, if they cannot be entirely solved."248 Some of the duke's men took this advice literally, like Diego López, head treasurer of the ducal rents and therefore the person in charge of collecting sales tax. After his arrest, he confessed "the friendship he had with the [squadron's] purveyor ... [with whom] he often went fishing, and they visited each other on special occasions. ... [and] they and their wives would go to the riverbank on summer evenings." Oddly enough, his friend the purveyor never visited him in prison, and after a calm period it seemed "a very obvious thing" to "have lost [for this reason] the friendship of the Adelantado [the Count of Santa Gadea]."249

Aside from the dangers of too-close friendships, experience showed that a minimal level of mutual understanding was the best way to ensure that "the chief ministers and their lieutenants and officers do justice without offending or extorting anyone."250 As the duke explained to his new corregidor in 1592, "The greatest difficulties in governing El Puerto de Santa María are the encounters with the captains general of the galleys ... who greatly exceed their jurisdiction and commission, causing great damage to mine and to my property,"251

246 AGs, CMC, 3 ápoca, 1436.

247 González, Censo de población, 84.

248 ADM, PSM 7, pieza 31.

249 ADM, PSM 8, pieza 38.

250 ADM, PSM 7, pieza 13.

251 ADM, PSM 7, pieza 75 . 
for they are "skilled in their good treatment of my vassals in the matter of buying their crops and paying for them well (and they must not allow my taxes to be evaded) and in many other things that always ensure friendship and pleasant relations." 252

There was even a permanent ducal commission for dealing with the situation, made up of the corregidor, the commander of the fortress, the duke's treasurer, and his chief scribe. Its only mission was "the defense of my jurisdiction ... in matters of captains general of the sea and the galleys," specifically to make them understand that "they have no right to do anything or take a hand in that city [El Puerto] and its jurisdiction any further than they have in Sanlúcar, Cádiz, and other seaports." It seems that after several years in which the galleys had made El Puerto their home port, their captains general had come to believe that their jurisdiction extended to the whole town; and the truth is that, with the help of their auditores, they had become highly effective in countering actions by the corregidores. The duke finally became so impatient with the problem that he sought out corregidores who would be less flexible and less obedient of the law: "So what we seek is to deny him [the Count of Santa Gadea] the bad habit he has acquired of usurping my jurisdiction, so he will see there is someone who will oppose him and face off with him ... as a legally trained corregidor would not."254

That remedy turned out to be worse than the disease. Soon after the first of those "lay" corregidores, Alonso de Cornejo, arrived in El Puerto, it began to be rumored that he "associates with fallen women, with whom it is said he has misbehaved," and, above all, that he was incapable of defending the duke's interests before the auditor of the galleys because "he is not an attorney and has no experience of what must be done."255 It seems that by the late sixteenth century so many townspeople had been made unofficial "crew members" of the galleys that any attempt to settle a dispute immediately met with "conflicts of jurisdiction" between the two legal systems. In 1594 Philip II ordered that the "membership" in the galleys, as soldiers and sailors, of all residents of El Puerto be canceled, on the grounds that "by living exempt from the justice of El Puerto ... they are emboldened to commit crimes." ${ }^{256}$

Apparently, it was impossible to keep auditores of the galleys from meddling in the town's legal affairs. ${ }^{257}$ Although every resident was subject to civil

$\begin{array}{ll}252 & \text { ADM, PSM 9, pieza } 22 . \\ 253 & \text { ADM, PSM } 7 \text {, pieza } 70 . \\ 254 & \text { ADM, PSM 7, pieza } 75 . \\ 255 & \text { ADM, PSM 9, pieza } 49 . \\ 256 & \text { ADM, PSM } 8 \text {, pieza } 21 . \\ 257 & \text { ADM, PSM 9, pieza } 67 .\end{array}$ 
justice, crimes related in any way to supplying the galleys, an activity in which many townspeople took part, fell under the captain general's jurisdiction. ${ }^{258}$ New legal infrastructure was built, in the form of a prison, to punish the many "public sins by murderers, blasphemers, thieves, cohabiters, ruffians, and other persons of ill repute ... [resulting from] the Galleys of Spain wintering here."259 The Medinaceli family never managed to collect sales taxes on provisions bought for the galleys on its lands, even after obtaining royal decrees in 1594, 1617 , and 1619 that ordered the squadron's officers to pay them. ${ }^{260}$ Still, the symbiotic relationship between the squadron and the town's income was probably greater than the dukes liked to admit, and dated back a long way. In 1568, when an outbreak of plague kept the galleys from anchoring in the river, that income suffered a severe blow — all the fresh bread and biscuit had to be thrown away because there was no one to buy it. ${ }^{261}$

According to a registry from March 1599, the Galleys of Spain employed 1,387 men among officers, soldiers, sailors, and rowers. ${ }^{262}$ Because about the same number of families lived in El Puerto de Santa María at the time, we can understand the significance of the galleys' arrival at the mouth of the Guadalete. Even more in that port than elsewhere, the prolonged presence of the squadron, with its large population and its prerogatives, made it difficult to assimilate its crew members in a jurisdictional sense. They influenced every aspect of daily life in El Puerto, as we see from the rapid turnover of corregidores and ducal treasurers, whose correspondence with the Duke of Medinaceli is full of conflicts with officers of the galleys. But all this was really the result of successful social and economic integration. In spite of the duke's complaints, many residents learned to exploit the jurisdictional advantages of the galleys' privileges in ways that improved their professional and commercial lives. Eventually, the distinction between crewmen and townspeople grew less clear. Ties of mutual interest caused the duke's income to decrease, much as the process of devassalage did-his former vassals kept their properties and professions in El Puerto but now obeyed a different authority, one that assumed the right to judge any criminal or economic offenses they committed. The case of $\mathrm{El}$ Puerto de Santa María illustrates how the galleys' economic privileges in provisioning and subsistence could alter the economic life of coastal towns. This generated jurisdictional disputes that may have been even more dangerous

258 ADM, PSM 9, pieza 6o.

259 ADM, PSM 9, pieza 46.

260 ADM, PSM 9, pieza 52 .

261 ADM, PSM 8, pieza 46 .

262 AGs, GyM, 541, 148. 
than those produced by occasional landings of soldiers, as their implications were much more profound and potentially more harmful to the interests of local authorities.

The risk resided not only in the squadron's fiscal exemptions that lowered local incomes but also in the frauds that ran along a parallel track. Many merchants gained by it, but the biggest winners were the crews. (All ranks took economic advantage of this favorable jurisdiction to the extent they were able.) Soldiers and slaves sold small items cheaply, both aboard and ashore, to make temporary improvements in their living conditions or save for their ransoms. Captains and skippers smuggled manufactured goods, money, and gunpowder, often in collusion with financial officers and even captains general. The latter used their jurisdiction to weave a dense network of contacts based on special favors, which often involved cheating on customs duties. But it was above all the purveyors, quartermasters, and other financial officers who were most clever at exploiting not only those deceptions but also the systematic theft of provisions and the funds meant to purchase them. Helped by the very local authorities who should have pursued their crimes, and by many merchants and captains, they developed a wide range of corrupt practices that were never seriously pursued by the Crown no matter how flagrant they became. A crucial factor in maintaining this corruption was the involvement of the families who managed the squadrons' logistics over generations, thanks especially to the patronage they enjoyed over all ranks of crew members.

We must consider whether this habitual corruption, in all its dimensions, helped to support and preserve the crews. Many members certainly gained more immediate and tangible benefits from this "lucre" than from captures of pirate ships or even from embargoes. Those practices, at least for the Galleys of Spain, normally did not yield much profit in prize money (which was distributed late and unevenly) or more efficient recruitment of rowers. Both those resources came not directly from warfare at sea but from a combination of more complex factors. Embargoes did not bring the squadrons much income either (in the form of auctioned ships or newly acquired convicts), because of diplomatic pressure by consuls and ambassadors. It is not strange, therefore, that the Galleys of Spain should cultivate smuggling much more than they condemned it, or that they had more to gain by trading with North Africa than by capturing ships along its coasts. The galleys' earnings from exporting grain, from ransoms, and from interference in North African civil strife outstripped their profits from corsair warfare. And this was true even though such warfare was in theory the spearpoint of the crusade, the preferred vehicle for a religious war between two supposedly irreconcilable opponents that left no room for collaboration or understanding. 
Officers of the galleys, in their unceasing search for provisions, established a broad range of relationships and strategies, both legal and illegal. All of these, however, were simply new ways of exercising the commercial rights of the ancient admiralties, which captains general inherited along with their jurisdiction. It is clear that the establishment of permanent squadrons of galleys, and the definition of their officers' responsibilities, at the end of the sixteenth century did more than change the administration of civil and criminal law in many coastal ports; they also influenced the development of commercial activities and the legal mechanisms for resolving conflicts connected to them. In the late 1500 s, galley tribunals controlled by their auditores consolidated a new model of justice whose jurisdiction extended not only to coastal trade but to seafaring itself. We cannot assess the full extent of its influence over maritime commerce, but the trials we know of almost always involved summary solutions, with armers and captains then forced into long waits after appealing to the Council of War. Still, the spread of these new tribunals into every squadron must have influenced contemporary thought about the freedom of the seas, and their existence reconfigured the jurisdictional map of the Mediterranean. To complete our analysis of all the ways in which captains general ruled their squadrons, and how their competencies and faculties were expressed, we must examine not only the fleets' external features but also their internal ones. 